\title{
Understanding Bank Risk through Market Measures
}

ABSTRACT Since the financial crisis, there have been major changes in the regulation of large banks directed at reducing their risk. Measures of regulatory capital have substantially increased; leverage ratios have been reduced; and stress-testing has sought to further assure safety by raising levels of capital and reducing risk-taking. Standard financial theories predict that such changes would lead to substantial declines in financial market measures of risk. For major banks in the United States and around the world and for midsized banks in the United States, we test this proposition using information on stock price volatility, option-based estimates of future volatility, beta, credit default swaps, price-earnings ratios, and preferred stock yields. To our surprise, we find that financial market information does not bear out the predictions of financial theory. Measures of volatility and risk premiums today are no lower and perhaps somewhat higher than they were prior to the financial crisis. We examine a number of possible explanations for our findings. While financial markets underestimated risk prior to the crisis and regulatory measures of capital are flawed, we believe that the most important explanation for our findings is the dramatic decline in the franchise value of major banks. We highlight that the ratio of the market value of common equity to assets on both a risk-adjusted and risk-unadjusted basis has declined significantly from the precrisis period to the current period for most major banks. As a consequence, banks are more vulnerable to adverse shocks. We argue for taking a dynamic view of capital that recognizes future profits as a source of capital, and urge approaches to financial regulation supervision that will reliably force rapid capital replenishment in difficult times - something that did not take place in the United States in 2008 and is not taking place in Europe today. 
oth within and outside the United States, reform of the financial system has been a central priority since the 2008 financial crisis. Policymakers and political commentators alike have heralded Dodd-Frank and Basel III as ushering in a new era of financial security. President Barack Obama proclaimed on the five-year anniversary of the crisis, "Our financial system is safer. . . . We put in place tough new rules on big banks" (Obama 2013). Federal Reserve chairwoman Janet Yellen concurs, noting, "We have put in place numerous steps and have more in the works that will strengthen these [financial] institutions, force them to hold a great deal of additional capital, and reduce their odds of failure.... There will be much lower odds that a so-called systemic firm would fail, and should that occur, we will have better tools to be able to deal with it" (Yellen 2014, p. 20).

At the heart of the regulatory reforms have been efforts to increase capital. Governor Mark Carney of the Bank of England observes that Tier 1 capital ratios for systemically important banks have more than doubled since 2009 and that capital requirements of the largest U.K. banks are in fact 10 times higher than before the financial crisis (Carney 2016a, 2016b). And taking into account adjustments in the definition of bank risk in the aftermath of the crisis, key officials such as Carney and Jaime Caruana, general manager of the Bank for International Settlements, claim that properly risk-adjusted capital levels brought about by Basel III for systemically important banks are seven times Basel II levels (Carney 2014; Caruana 2012).

According to standard financial theories, the idea that banks are better capitalized and hold fewer risky assets has clear implications for the pricing of their securities. With less leverage, bank equity should be less volatile, and there should be less market expectation of future volatility. Bank stocks should also be less responsive to movements in overall economic conditions. As a consequence of reduced risk, the expected return on bank debt, bank preferred stock, and common stock should be reduced. This last idea, that reduced riskiness should translate into lower required returns on stock, is central to the influential arguments put forth by Anat Admati and Martin Hellwig (2013) that increasing capital requirements promotes safety without significantly raising overall capital costs.

In this paper, we use a range of financial market data to examine implicit market judgments about the safety of banks. Any individual indicator is an imperfect proxy for financial risk; however, looking at many different indicators enables an assessment of market beliefs. In examining volatility, we focus on historical stock price volatility, expected volatility as 
implied by traded options, beta - the standard measure of comovement with the market-and a measure of contribution to systemic risk devised by Viral Acharya and others (2017). In investigating expected returns, we look at credit default swap (CDS) spreads as a measure of the riskiness of unsecured bank debt, preferred stock yields, and price-earnings (PE) ratios as a proxy for expected stock market returns.

We look at data for the "Big 6" U.S. banks-Bank of America, Citigroup, Goldman Sachs, JPMorgan Chase, Morgan Stanley, and Wells Fargo- as well as the largest non-Chinese banks outside the United States. We also consider a broader range of domestic banks, analyzing the 50 largest U.S. banks outside the Big 6, as measured by total assets.

To our surprise, capital market information is at least superficially inconsistent with the prediction that since banks are much better capitalized, their riskiness has declined and required returns on their securities have come down. If anything, measures of volatility appear to be higher postcrisis than they were precrisis, and measures of expected returns are higher as well. These tendencies are even stronger outside the United States, perhaps reflecting greater regulatory progress in the United States. ${ }^{1}$ They are about equally pronounced for the Big 6 banks and for midsize banks; and they are strongest for the smallest banks in our sample, a finding that is perhaps unsurprising, given that much greater regulatory effort has gone into reducing risk in large banks.

We examine a number of possible explanations for our anomalous findings. It is plausible that markets underestimated risks in the immediate precrisis period. We find some evidence for this in our paper, although the current measures of volatility and beta remain elevated even relative to earlier periods. We suspect that measures of regulatory capital are flawed as measures of economic capital. Thus, properly measured capital may have increased less than regulatory capital measures, and this may account for part of what we find.

One important explanation for our findings is that the franchise value of banks has substantially decreased in the wake of the financial crisis. This is reflected in sharp declines in the ratio of price-to-book value for most banks in our sample. Essentially equivalently, the ratio of the market value of equity to assets has declined on a risk-adjusted or risk-unadjusted basis for most banks. With a lower level of equity relative to assets, it is not

1. Note that there are of course several factors that lead to the different experiences for the U.S. banking sector relative to that of other countries, for example, the greater exposure of European banks to the eurozone sovereign debt crisis. 
surprising that volatility has gone up or that the riskiness of bank debt has increased. Critically, a lower ratio of market value of equity to total assets for a bank means that the proportional loss on assets sufficient to cause insolvency has decreased.

Our results do not call into question the desirability of the increases in capital that have been mandated by postcrisis regulations. Indeed, we suspect that without increases in capital requirements, levels of volatility would have increased even more than we observe. But they do counsel against complacency and highlight future policy challenges. We argue that the risk of insolvency for major banks may not have been reduced as much as is generally supposed. In some cases, there may be a case for increasing capital requirements. But we believe that more effective than increasing capital requirements will be steps to assure prompt response to situations where markets suggest capital shortfalls. Such steps were not taken in the first half of 2008 in the United States and do not appear to be in place in Europe today. While the issue of bank runs on healthy institutionsthe idea that a bank can be illiquid without being insolvent-has received much attention, we direct attention to the notion that banks can be insolvent without being illiquid.

This paper is organized as follows. Section I motivates our risk measures and evaluates the expected effect of a substantial increase in bank capital on these measures. Section II discusses our data sources. Section III presents results for these risk measures for the six major U.S. banks. Section IV considers a broader range of domestic banks. Section V presents corresponding results for international institutions. Section VI considers a number of possible explanations for our findings and focuses attention on the ratio of the market value of equity to assets as a crucial risk measure. Section VII concludes by discussing remaining uncertainties, issues for further research, and possible policy implications.

\section{Review of Risk Measures}

The standard frameworks used in bank regulation and supervision place little emphasis on the pricing of bank liabilities and bank equity in evaluating the riskiness of banks. These frameworks are the basis for assertions that the financial system has become far safer.

It is noteworthy that, as Jeremy Bulow and Paul Klemperer (2013, 2015) and Andrew Haldane (2014) point out, measures of regulatory capital have historically not had much predictive power for bank failures. Bear Stearns, Wachovia, Washington Mutual, Fannie Mae, and Freddie 
Mac were all seen by their regulators as well capitalized immediately before their failures. In fall 2008 testimony before the House Committee on Oversight and Government Reform, chairman of the U.S. Securities and Exchange Commission Christopher Cox stated,

The rapid collapse of Bear Stearns during the week of March 10, 2008, challenged the fundamental assumptions behind the Basel standards and the other program metrics. At the time of its near-failure, Bear Stearns had a capital cushion well above what is required to meet supervisory standards calculated using the Basel framework and the Federal Reserve's "well-capitalized" standard for bank holding companies. The fact that these standards did not provide enough warning of the near-collapse of Bear Stearns, and indeed the fact that the Basel standards did not prevent the failure of many other banks and financial institutions, is now obvious. (Cox 2008)

Relatedly, Lehman Brothers was more than adequately capitalized on paper — with a Tier-1 capital ratio of 11.6 percent-shortly before its 2008 bankruptcy (Johnson and Kwak 2010). The average Tier-1 capital ratio of the Big 6 prior to the crisis (8.4 percent) was well below that of Lehman Brothers immediately before its collapse. And banks that eventually failed or were major beneficiaries of government funds through the Troubled Asset Relief Program (TARP) did not even restrict dividends during the crisis epoch-Lehman Brothers announced a 13 percent increase in its dividends and a $\$ 100$ million share repurchase in January 2008, Citigroup waited until November 2008 to cut its dividends, and Wells Fargo and JPMorgan Chase, who received TARP capital in the fall of 2008, did not cut dividends until the spring of 2009 (Acharya, Shin, and Gujral 2009).

In contrast, the pricing of the equity and debt securities of these financial institutions was signaling distress. Dramatic stock price declines for large U.S. financial institutions began well before Bear Stearns collapsed in the spring of 2008 (Gehrig 2016). It therefore seems worthwhile to use information on bank security prices in evaluating their safety. In this section, we review the risk measures we use to evaluate the impact of regulatory changes on systemically important banks. We also explain the anticipated impact of increased capital requirements on these measures. For robustness and in order to assess what factors are behind movements in risk, we look at a variety of indicators.

\section{I.A. Volatility}

Standard financial theory holds that reductions in leverage or, equivalently, increases in capital should lead to declines in volatility. William 
Schwert (1989) models the relationship between stock volatility and leverage. He notes that the variance of the return on assets of a firm is given by

$$
\sigma_{v t}^{2}=\left(\frac{S_{t-1}}{V_{t-1}}\right)^{2} \sigma_{s t}^{2}+\left(\frac{B_{t-1}}{V_{t-1}}\right)^{2} \sigma_{b t}^{2}+2\left(\frac{S_{t-1}}{V_{t-1}}\right)\left(\frac{B_{t-1}}{V_{t-1}}\right) \operatorname{cov}\left(R_{s t}, R_{b t}\right),
$$

with $\sigma_{v t}^{2}$ as the variance of the return on the assets of a firm, $\sigma_{s t}^{2}$ as the variance of the returns on stock, $\sigma_{b t}^{2}$ as the variance of the bond returns, and $\operatorname{cov}\left(R_{s t}, R_{b t}\right)$ as the covariance of the bond and stock returns. Assuming a firm with riskless debt implies

$$
\sigma_{b t}^{2}=\operatorname{cov}\left(R_{s t}, R_{b t}\right)=0 .
$$

We are left with the standard deviation of stock returns as

$$
\sigma_{s t}=\sigma_{v t}\left(\frac{V_{t-1}}{S_{t-1}}\right)
$$

$V / S$ is the financial leverage ratio - the ratio of assets to equity. Thus, the relationship between stock volatility and leverage is linear, with a slope equal to the volatility of the return on firm assets. If effective leverage has been reduced by regulatory changes in a way that has not been offset by an increase in the volatility of bank assets, one would expect to see the volatility of bank equity go down.

The assumption of riskless debt above is justified based on Malcolm Baker and Jeffrey Wurgler (2015), who study the relationship between beta and leverage. Replicating their methodology for our sample, we estimate an asset beta of approximately 0.081 in the cross section. Since asset beta must mechanically be higher than debt beta, like Baker and Wurgler, we conclude that the zero estimate for debt beta is a reasonable one. ${ }^{2}$

In reality, bank debt is not riskless and fluctuates in value with bank assets; and banks sometimes raise equity of their own volition or at the behest of regulators, creating a wedge between movements in stock prices and movements in the total market value of equity. For all these reasons, the relationship between leverage and volatility is not likely to be perfectly linear. Nonetheless, it is reasonable to expect that if banks have

2. This is slightly above Baker and Wurgler's (2015) estimate of 0.074 , which is likely related to the difference in our samples-Baker and Wurgler consider all domestic bankholding companies, while we restrict our attention to the largest ones. We discuss Baker and Wurgler (2015) more extensively below. 
become materially safer and if they are less levered, their equity volatility should go down.

Note that the risk of insolvency is closely related to volatility. Banks fail when their equity value falls below zero or some threshold close to zero. Leaving aside the possibility of new equity issues, the likelihood of reaching this threshold depends on their volatility. If one assumes that dollar volatility is constant as the value of equity declines (implying a proportional increase in percentage volatility), then the probability of the stock price reaching zero over a given interval is readily calculable. Suppose, for example, that a bank has 30 percent annualized volatility. Then leaving aside expected appreciation in its stock, it would require a 3.33 standard deviation move in one year for its equity to go to zero, or a 1.67 standard deviation move in four years. ${ }^{3}$

Many will suspect that markets now expect that banks are less likely to be bailed out than previously. We are not sure whether this is a valid suspicion nor whether markets have it. But most regulators have been focused on reducing the likelihood that a bailout will be needed as opposed to taking the kind of actions that make it credible that a bailout will not be provided in bad times. Equity volatility along with debt risk premiums suggest we should have concerns about this approach.

One issue with volatility as a measure of risk is that it does not benchmark naturally against changes in the market. An increase in volatility could reflect overall changes in investor sentiment about the market rather than specific beliefs about the large banks we study. As such, we also construct a relative volatility measure-dividing the volatility of our large banks by the volatility of the S\&P 500 - and use this relative volatility measure to study the impact of financial reform on market assessments of bank risk.

\section{I.B. Implied Volatility}

Volatility can be measured using historical stock price data or inferred from options data, and the latter exercise allows us to ascertain the market's expectation of future volatility. Bent Christensen and Nagpurnanand Prabhala (1998) find that implied volatility outperforms historical volatility in predicting future volatility; and Charles Cao, Fan Yu, and Zhaodong

3. This basic back-of-the-envelope calculation assumes that new equity will not be issued as banks begin to fail. Measures we discuss below (like CDS spread and preferred stock yields) take into account the market's assessment of the likelihood of dilutive equity issuances in times of distress. 
Zhong (2010) come to the same conclusion, noting that implied volatility is a better predictor of CDS spreads than realized volatility because information about the volatility risk premium is embedded in option prices. ${ }^{4}$ Thus, for completeness, we use both realized and implied volatility as risk measures-along with relative realized and implied volatility benchmarked against the S\&P 500 - and study their responsiveness to decreases in banks' leverage.

\section{I.C. Out-of-the-Money Put Option Delta}

As we have noted, the solvency of a bank has to do with the chance of its equity value going to zero. This may be better reflected in the valuation of out-of-the-money (OTM) options than in either observed volatility or the volatility implicit in at-the-money options. For an analysis of lowprobability catastrophes and option pricing, see Robert Barro and Gordon Liao (2016).

Given that bank stock prices-and relatedly, volatility—can and do move frequently, it is instructive to look at OTM deltas as reflecting the likelihood of low-probability major movements in stock price. To examine major event risk, we note that the absolute value of the option delta is the market assessment of the probability of the option ending up in the money (Gunn 2009). As such, we calculate the delta on a one-year, 50 percent OTM put option to ascertain the probability of a major fall in stock price in the next calendar year and use this delta as a supplemental risk measure.

In order to calculate the delta of a 50 percent OTM put option, we take the most OTM put option (with more than two months to expiration) on each day in the precrisis and postcrisis periods. ${ }^{5}$ We use the implied volatility on these far OTM options to calculate an annual average implied volatility, and we follow the Black-Scholes model (Pacati 2013) to compute a delta on an exactly 50 percent OTM option with one year to expiration. ${ }^{6}$

4. Note that their analysis is not specific to bank CDS spreads, which are slightly distinct from CDS spreads generally because bailout probabilities are embedded in these spreads for large financial institutions.

5. Volatility differs across different classes of options, and here we focus on the volatility of those far OTM put options that are related to the likelihood of a large decline in equity value.

6. We use daily data on risk-free rates from a 12-month Treasury bill, and add in dividend yield data for our banks. We use the Black-Scholes model to compute option deltas. Dividend yield data are available quarterly. 
Since a decrease in leverage should decrease the likelihood of default, we expect increased capital requirements to decrease (in absolute value terms) the OTM put delta. More simply, if banks are safer, the market assessment of the probability that they will lose half their equity value in the next year should go down.

\section{I.D. Beta}

The volatility of a bank's equity may reflect news about its particular position or the quality of its management. An alternative way to get at the extent to which a bank is levered is to look at the response of its value to moves in the overall market, as reflected in its beta.

Baker and Wurgler (2015) seek to understand the impact of stringent capital requirements on the cost of capital. They focus on beta as a measure of equity risk and discuss the impact of bank leverage on firm beta. We adopt their framework in considering the impact of a decrease in banks' leverage on equity betas. Arithmetically, we know that the following relationship holds for equity, debt, and asset beta:

$$
\beta_{a}=e \beta_{e}+(1-e) \beta_{d},
$$

with $\beta_{a}$ as asset beta, $\beta_{e}$ as equity beta, $\beta_{d}$ as debt beta, and $e$ as the ratio of equity to total assets. $1 / e$ is the inverse capital ratio, equivalent to Schwert's $V / S$ above. We again assume that the riskiness of bank assets is constant, that is, that $\beta_{a}$ has not changed. When Baker and Wurgler (2015) rearrange the equation above and assume riskless debt, they conclude that, like volatility, the relationship between beta and leverage is linear, with a slope equal to the asset beta.

Baker and Wurgler verify that this relationship holds true to a substantial extent in the cross section. ${ }^{7}$ We replicate their results using our data on large and midsize domestic banks. We compute forward beta following their methodology, by regressing a minimum of 24 months and a maximum of 60 months of future holding period returns on the value-weighted market returns produced by the University of Chicago's Center for Research in Security Prices (CRSP), both in excess of the riskless rate. As a measure of leverage, we use the quarterly Tier 1 leverage ratio from bank call reports. Figure 1 presents the relationship between bank beta and leverage in our

7. Baker and Wurgler (2015) find an approximately linear relationship between leverage and bank beta using returns and capitalization data for nearly 4,000 publicly traded banks or holding companies that appear in CRSP between 1970 and 2011. 
Figure 1. Beta and Bank Leverage ${ }^{a}$

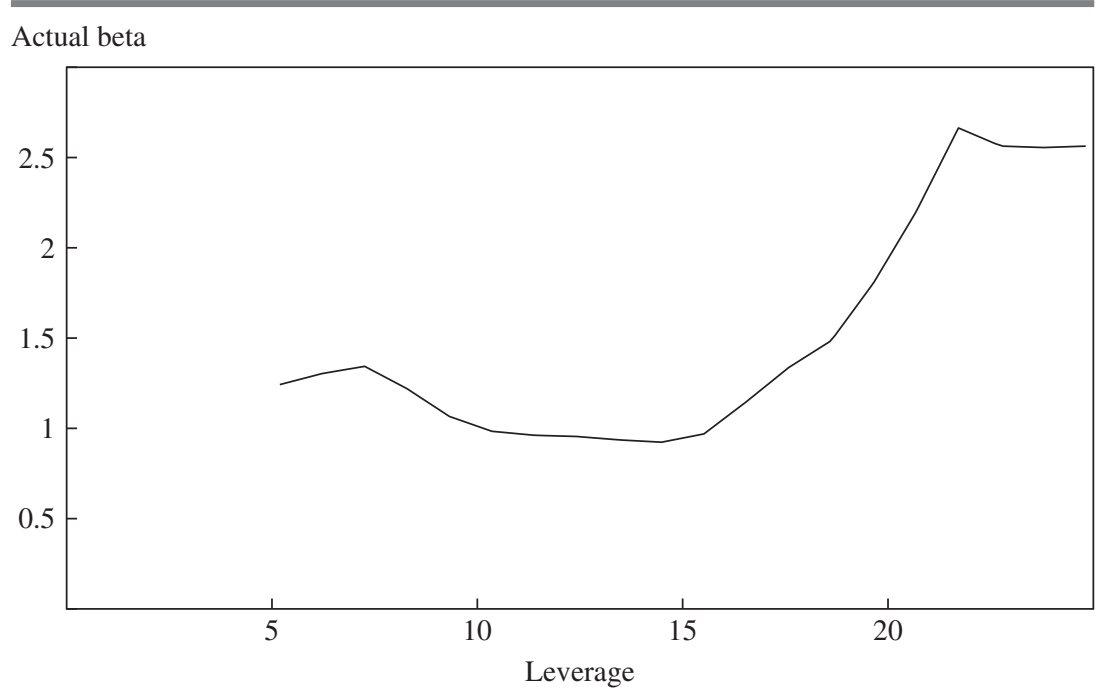

Sources: Authors' calculations; bank call reports; Bloomberg.

a. Following Baker and Wurgler (2015), the dependent variable is forward beta, and the independent variable is the ratio of total risk-based capital to tier 1 capital. The data set contains more than 6,000 bank-months. We report results from local polynomial regressions using an Epanechnikov kernel with 20 bins and a smoothing interval of 0.1 .

cross section. ${ }^{8}$ Like Baker and Wurgler (2015), we see that this relationship is linear over most of the range of leverage, with a slight S-shape that Baker and Wurgler attribute to the inclusion of what they call "extreme levels" of leverage in the sample.

These cross-sectional results confirm the idea that beta should fall with leverage. In this spirit, we look at movements over time in bank betas to reach a judgment about their degree of effective leverage.

\section{I.E. Credit Default Swap Spread}

The CDS spread is the annual cost of protection against a default by a company. CDS spreads should rise with leverage, as the probability of

8. Although we present only the results for the local polynomial regression in figure 1, we note that since our sample is much smaller than Baker and Wurgler's (only about 6,000 bank-months, versus their sample of over 74,000), nonparametric analysis may be ill suited here. While we think this visual is powerful, we also run a basic regression of beta on leverage. The results show a positive and statistically significant relationship, and when we suppress the constant, which corresponds to Baker and Wurgler's assumption of riskless debt, we have a point estimate of 0.081 for asset beta, very close to Baker and Wurgler's estimate of 0.074 . 
default is increased as firms become more levered (Collin-Dufresne, Goldstein, and Martin 2001). Consequently, all else equal, the increased capital requirements in the wake of the financial crisis should have decreased CDS spreads.

More generally, if banks are now less likely to fail, their CDS spreads should be lower. There is, of course, the possibility that CDS spreads move not because of changes in bank riskiness but because of changes in the probability of a government bailout. That is why we examine them, as described above, alongside option-based estimates of the probability of a large decline in bank stock prices. If CDS spreads were rising only because of a reduction in the prospect of a government bailout, one would not expect to see simultaneous increases in the probability of a large drop in stock prices.

\section{I.F. Price-Earnings Ratio}

Raghuram Rajan (2005) compares the PE ratios of banks in the United States relative to the market and proposes that the declining relative PE ratios imply that the market discounts bank earnings with an increasing risk premium. He suggests this as evidence that (at the time) banks had not become less risky as the result of global financial development in the prior three decades.

We follow Rajan (2005), but focus on a different epoch. We compare bank PE ratios relative to the S\&P 500 in the precrisis versus postcrisis periods and expect that an increase in bank capitalization should decrease risk-and thus increase relative PE ratios.

\section{I.G. Preferred Stock Price and Yields}

Relatedly, we examine the pricing of preferred stock both before and after the Great Recession. Preferred stock is a layer of capital that is junior to debt, and its holders are entitled to a fixed or floating (indexed to the London Interbank Offered Rate, LIBOR) dividend whose payment takes priority over dividend payments to common shareholders. Preferred stock has a unique feature of being callable, meaning its holders can be bought out, if the firm decides that the payout (or stream of future payouts) is large relative to the value of the share.

Since preferred stock has debt-like features, we can infer from the price of these shares how the market perception of bank risk has evolved in the aftermath of the Great Recession. Given that long-term riskless rates have declined substantially since the precrisis period, we would expect that if banks are no riskier today (or even less risky, given the large influx of 
capital as a result of postcrisis regulation), preferred shares should be selling for substantially more today than they were in the precrisis period. We would also anticipate that yields on preferred stock should have declined in the aftermath of the crisis and that yields on new preferred stock issuances should be low.

\section{I.H. Systemic Risk Contribution}

Acharya and others (2017) focus on a new definition of a firm's systemic risk. They define systemic risk not in terms of the likelihood of an individual financial firm's failure, but rather by the likely size of a firm's contribution to a system-wide failure. Their systemic risk measure is equal to the product of three components: (i) the real social cost of a crisis per dollar of capital shortage; (ii) the probability of a crisis; and (iii) the expected capital shortfall of the firm in a crisis.

They compare their measure with standard measures of institutionlevel risk, such as volatility and beta, and find that while these standard measures do a relatively poor job of predicting which institutions fare worst in a crisis, their systemic risk measure explains a high proportion of realized returns during the Great Recession. Thus as an additional financial market indicator of bank stability, we examine whether Acharya and others' (2017) measure reflects a decline in systemic risk since the financial crisis.

\section{Data Sources}

The data we use in this paper are derived from numerous financial databases.

\section{II.A. Domestic Data}

We collect daily data on beta and historical volatility from Bloomberg. To compare historical volatility with market volatility, we divide by market volatility for each day. ${ }^{9}$ Market volatility is given by the realized volatility of the S\&P 500. To compute annual averages, we take the average of the prior 260 trading days' volatilities.

We collect daily data on implied volatility from Bloomberg as well. The implied volatility is the annualized volatility on the nearest contract, which generally will be expiring within the next 30 days. As with historical

9. We also subtract out market volatility, yielding similar results. These are available upon request. 
volatility, to compare implied volatility with market volatility, we divide by market volatility each day..$^{10}$ Market implied volatility is given by the Chicago Board Options Exchange's Volatility Index (VIX), a measure of the implied volatility of S\&P 500 stock index option prices.

We collect CDS data from S\&P Capital IQ. We use price data for a fiveyear tenor. Acharya and others' (2017) systemic risk metric comes from New York University's Volatility Institute.

We compute our financial ratios using data from the Center for Research in Security Prices, Compustat, and Bloomberg. The PE ratio is daily stock price (from CRSP) divided by earnings per share (from Compustat). Priceto-book data come from Bloomberg. The ratio of market value of equity to assets is computed as the multiple of price and shares outstanding (from CRSP), divided by assets data (from Bloomberg). Information on preferred stock offerings and daily price data comes from the New York Stock Exchange's online database.

\section{II.B. International Data}

We collect daily data on beta, CDS spreads, and price-to-book ratios from Thomson Reuters Datastream. We calculate international betas relative to the country index for each of our banks. We get data on firm volatility and implied volatility from Bloomberg, and we match this with country volatility, ${ }^{11}$ and country implied volatility indexes, ${ }^{12}$ also from Bloomberg.

Bloomberg LIVE provides us with implied volatility data for our international banks. The Bloomberg LIVE calculator uses listed option market data to generate implied volatility figures. Specifically, it weighs the nearest two option series that are at the money, one above and one below the underlying price. ${ }^{13}$

10. As above, results are comparable when we subtract out market volatility.

11. Because of data availability, we benchmark banks in Denmark, the Netherlands, and Sweden against European realized volatility indexes rather than country-specific ones.

12. Because Australia, Brazil, and Canada only recently added implied volatility indexes, in these countries we benchmark against the U.S. VIX. We benchmark banks in Denmark, France, Italy, the Netherlands, Spain, Sweden, and Switzerland against a European implied volatility index because country-specific data are not available. We believe this is a reasonable approach, given the extremely high correlation between the various country-specific indexes and regional ones. See Liu (2012).

13. Reuters uses a similar methodology, and explains it as follows: "The Datastream calculations take into account the at-the-money implied volatility interpolated between one strike above and one below the underlying price" (Thomson Reuters 2008, p. 16). 


\section{Summary of Results}

In table 1, we summarize the results for each of the risk measures. We compare the precrisis period (typically from 2002 to 2007) with the postcrisis period (typically from 2010 to 2015), and we seek to determine how the risk profile of our financial firms has evolved in the aftermath of the crisis. We exclude 2008 and 2009 from our sample based on the National Bureau of Economic Research's (NBER's) classification of the Great Recession, which officially began in December 2007 and ended in June 2009. ${ }^{14} \mathrm{We}$ begin our precrisis period in 2002, also following the NBER, in efforts not to contaminate our precrisis period with previous cyclical downturns. Before the Great Recession, the last official recession began in March 2001 and ended in November 2001. Our estimates are robust to defining "crisis" as July 2007 to December 2008, following Acharya, Hyun Song Shin, and Irvind Gujral (2009), or as January 2007 to September 2008, following David Erkens, Mingyi Hung, and Pedro Matos (2012), although past work has also used December 2007 as the starting date for the Great Recession (Elsby, Hobijn, and Şahin 2010; Katz 2010). The top panel of table 1 provides the results for the Big 6 U.S. banks, the middle panel provides the results for the midsize U.S. banks (by total assets, excluding the Big 6), and the bottom panel provides the results for the largest banks outside the United States and China.

Figure 2 illustrates how several of our risk measures have evolved over time for the Big 6 banks, midsize domestic banks, and international banks. We see that while risk beta, volatility, and CDS spread peaked during the Great Recession, these measures remain elevated in the postcrisis period. Our preferred specification involves comparing the precrisis period with the most recent 2015 crisis measures, where our baseline results continue to hold.

We find that, based on virtually all our measures, firms have become riskier in the postcrisis epoch. At least superficially, capital market measures do not suggest that banks have become safer as a result of enhanced regulation in the form of higher capital requirements. Below, we discuss specific results for each of our risk measures. We first provide results for

14. We extend our crisis period through December 2009, but results are even stronger when the second half of 2009 is included in our postcrisis period as per the NBER's classification. We exclude the second half of 2009 from the postcrisis period because we do not want to capture any of the residual impact of the Great Recession. We also favor a more conservative estimate of bank risk in the postcrisis period. 
Table 1. Summary of Bank Data

\begin{tabular}{|c|c|c|c|}
\hline Measure & $\begin{array}{l}\text { Precrisis } \\
\text { average }\end{array}$ & $\begin{array}{l}\text { Postcrisis } \\
\text { average }\end{array}$ & $\begin{array}{c}2015 \\
\text { average }\end{array}$ \\
\hline \multicolumn{4}{|l|}{ Big 6 U.S. banks } \\
\hline Volatility & 24.70 & 33.47 & 20.67 \\
\hline Ratio of bank volatility to market volatility ${ }^{a}$ & 1.55 & 1.78 & 1.71 \\
\hline Implied volatility ${ }^{\mathrm{b}}$ & 22.90 & 30.77 & 22.96 \\
\hline $\begin{array}{l}\text { Ratio of implied bank volatility to implied } \\
\text { market volatility }\end{array}$ & 1.91 & 2.14 & 1.61 \\
\hline Option delta ${ }^{c}$ & 0.036 & 0.074 & 0.046 \\
\hline Beta & 1.18 & 1.61 & 1.23 \\
\hline CDS spread ${ }^{\mathrm{d}}$ & 31.85 & 140.63 & 93.58 \\
\hline Ratio of bank PE ratio to market $\mathrm{PE}$ ratio ${ }^{\mathrm{e}}$ & 0.67 & 1.22 & 0.68 \\
\hline Preferred stock price ${ }^{f}$ & 24.97 & 20.25 & 20.74 \\
\hline Systemic risk contribution (percent) & 4.76 & 8.25 & 7.68 \\
\hline \multicolumn{4}{|l|}{ Midsize U.S. banks } \\
\hline Volatility & 25.54 & 30.11 & 21.61 \\
\hline Ratio of bank volatility to market volatility ${ }^{\mathrm{a}}$ & 1.68 & 1.66 & 1.78 \\
\hline Implied volatility ${ }^{\mathrm{b}}$ & 25.62 & 32.06 & 26.79 \\
\hline $\begin{array}{l}\text { Ratio of implied bank volatility to implied } \\
\text { market volatility }\end{array}$ & 2.15 & 2.31 & 1.91 \\
\hline Beta & 0.96 & 1.29 & 1.05 \\
\hline CDS spread ${ }^{\mathrm{d}}$ & 23.02 & 94.00 & 67.91 \\
\hline Ratio of bank PE ratio to market $\mathrm{PE}$ ratio & 0.79 & 0.75 & 0.73 \\
\hline \multicolumn{4}{|l|}{ International banks } \\
\hline Volatility & 26.55 & 32.73 & 25.57 \\
\hline Ratio of bank volatility to market volatility ${ }^{a}$ & 1.52 & 1.72 & 1.43 \\
\hline Implied volatility ${ }^{\mathrm{b}}$ & 22.10 & 31.36 & 27.27 \\
\hline $\begin{array}{l}\text { Ratio of implied bank volatility to implied } \\
\text { market volatility }\end{array}$ & 1.36 & 1.50 & 1.36 \\
\hline Beta & 0.80 & 1.07 & 0.99 \\
\hline CDS spread ${ }^{\mathrm{d}}$ & 13.66 & 129.13 & 103.66 \\
\hline
\end{tabular}

Sources: Acharya and others (2017); Bloomberg; Capital IQ; Compustat; CRSP; Datastream; New York Stock Exchange's online database; Volatility Institute.

a. For domestic comparisons, we use the market return of the S\&P 500, and the standard deviation of the daily return over 260 trading days to approximate an annual average. For international comparisons, we use local indexes except for banks in Denmark, the Netherlands, and Sweden; we benchmark volatility of banks in these countries against the European index.

b. The earliest implied volatility data are available in 2005. For domestic comparisons, we use the U.S. VIX. For international comparisons, indexes are rather scarce; as such, we benchmark against a European implied volatility index except for Australian, Brazilian, and Canadian banks, which we compare to the U.S. VIX.

c. This is the delta on a one-year, 50 percent OTM put option. Monthly option data are only available through June 2015, so we use the 2014 average as the most recent annual measure.

d. The earliest CDS data available are from February 2004. These are the data for a five-year tenor.

e. We follow Rajan (2005) and examine the bank PE ratio as a percentage of the S\&P 500 PE ratio.

f. There are only three banks in our sample_-Bank of America, Goldman Sachs, and Morgan Stanleywith floating-rate preferred stock dating back to the precrisis period. 
Figure 2. Changes in Risk Measures, 2002-15

Big 6 U.S. banks

Volatility

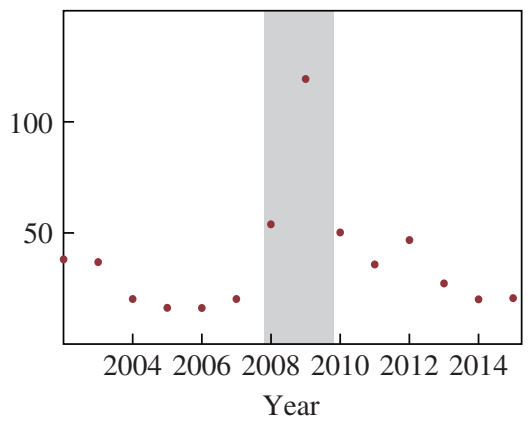

Implied volatility

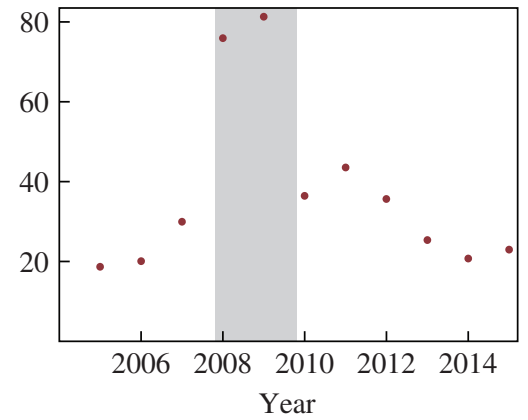

Beta

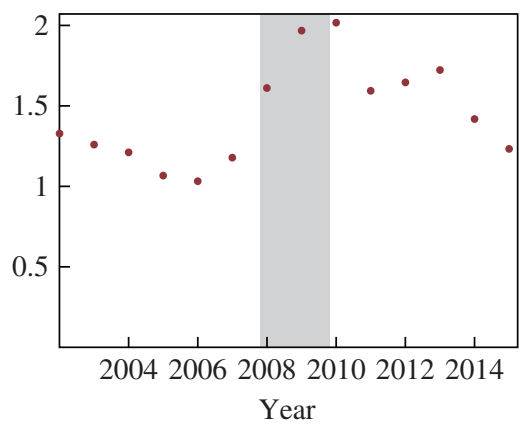

Ratio of bank volatility to market volatility

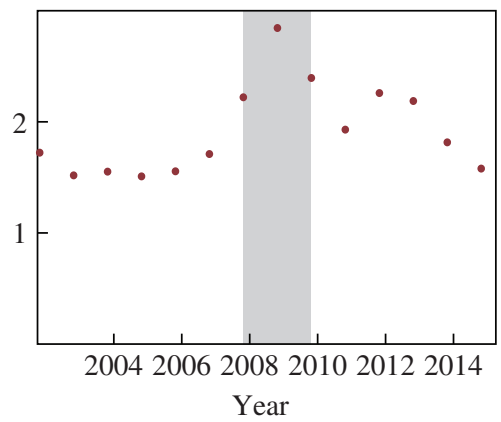

Ratio of implied bank volatility to implied market volatility

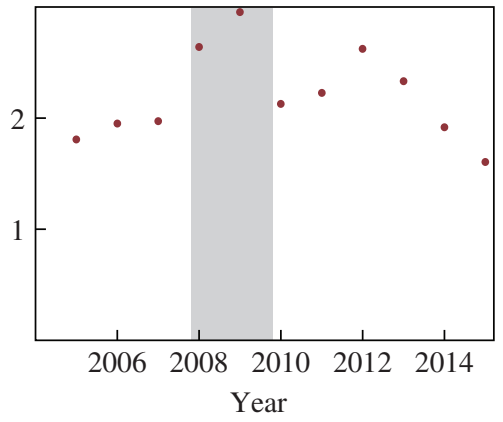

Credit default swap spread

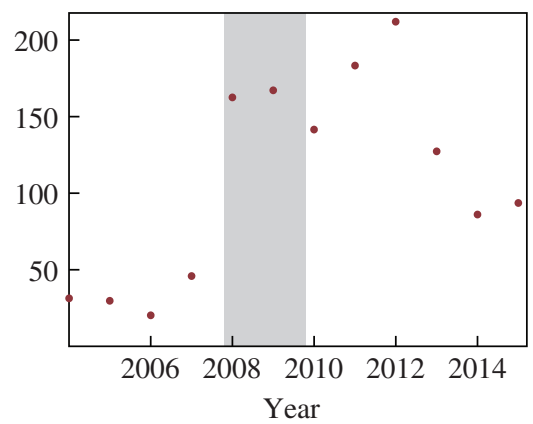


Figure 2. Changes in Risk Measures, 2002-15a (Continued)

\section{Midsize U.S. banks}

Volatility

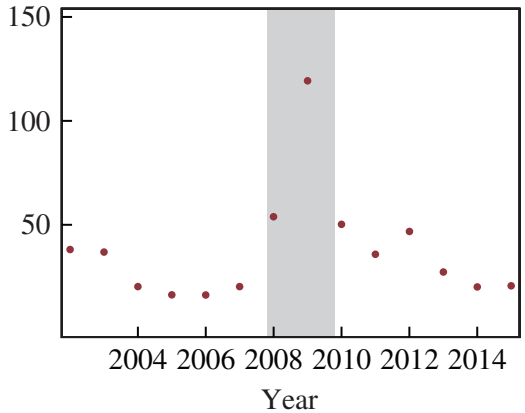

Implied volatility

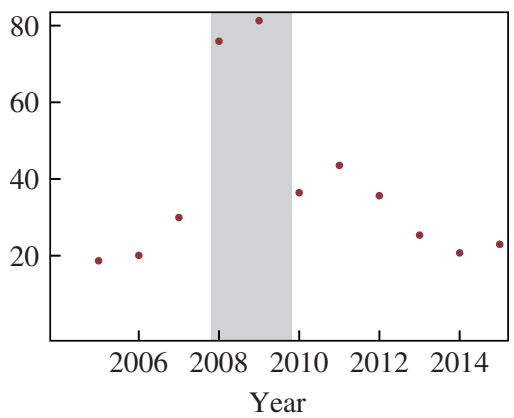

Beta

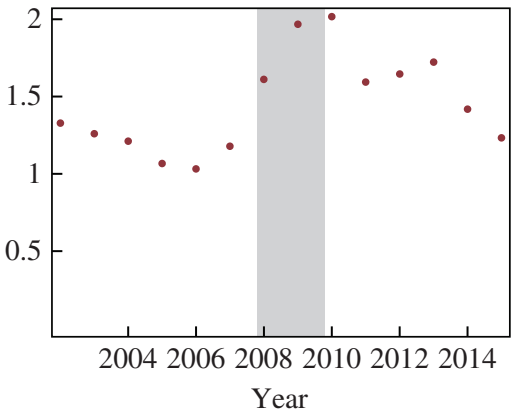

Ratio of bank volatility to market volatility

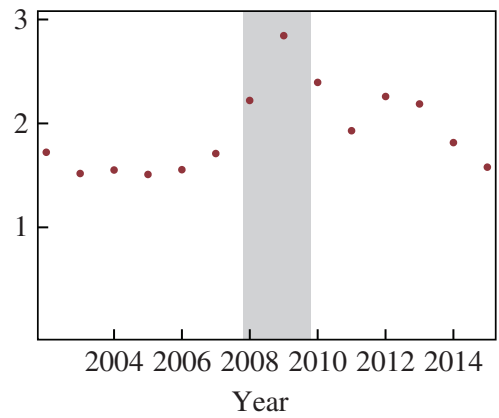

Ratio of implied bank volatility to implied market volatility

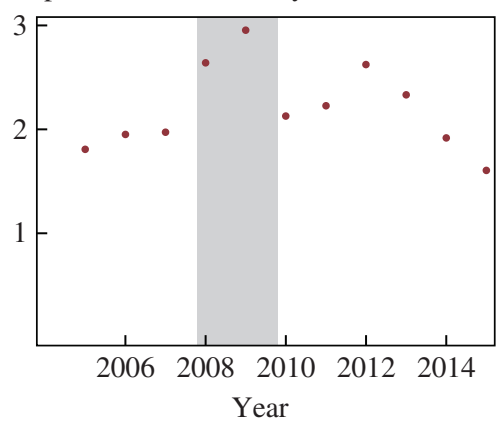

Credit default swap spread

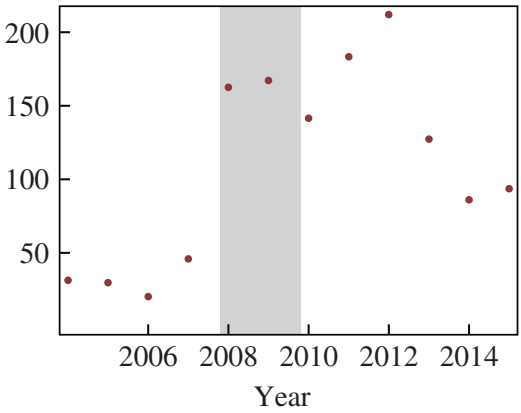

(continued) 
Figure 2. Changes in Risk Measures, 2002-15a (Continued)

\section{International banks}

Volatility

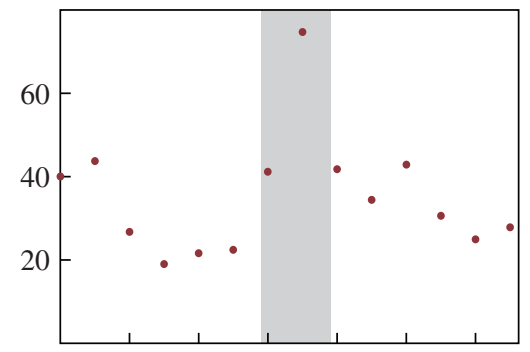

200420062008201020122014

Year

Implied volatility

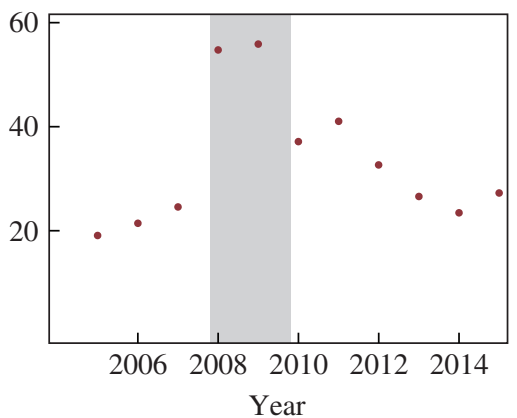

Beta

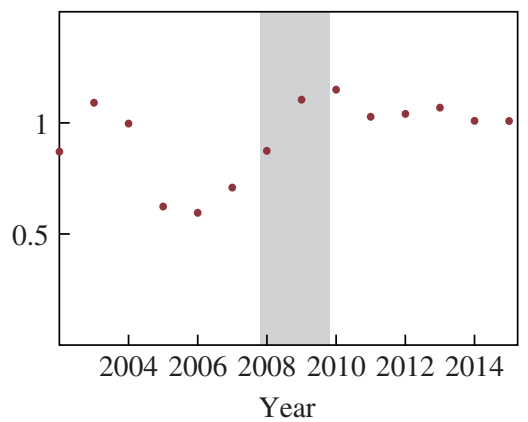

Ratio of bank volatility to market volatility

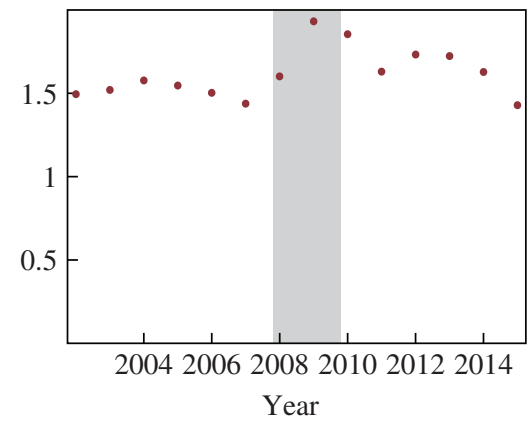

Ratio of implied bank volatility to implied market volatility

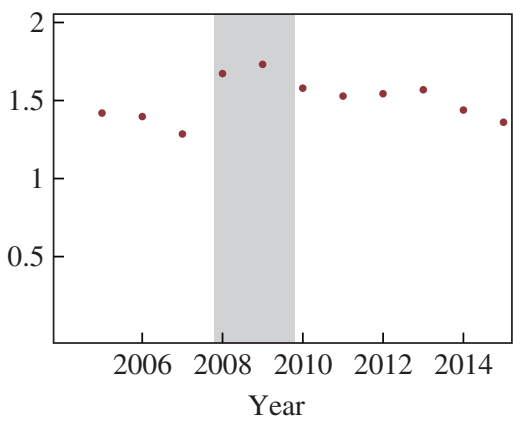

Credit default swap spread

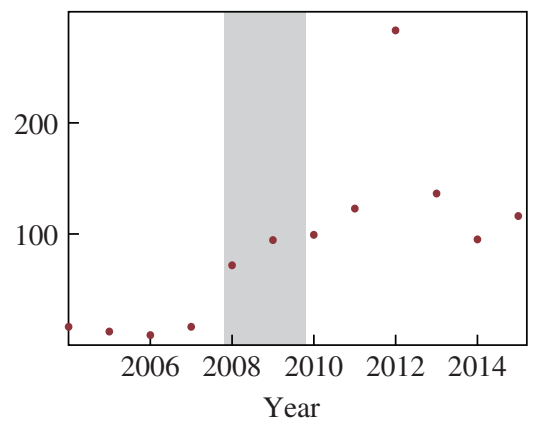

Sources: Bloomberg; Capital IQ; Datastream.

a. The shaded regions indicate crisis years, 2008-09 in our sample. 
the Big 6, and then look at a wider range of U.S. banks and international banks to further bolster our baseline results.

\section{III.A. Volatility}

We expect that volatility decreases with decreased leverage, and consequently hypothesize that volatility is lower in the postcrisis period. However, looking at the Big 6 banks, we find that this is not the case. Particularly, in appendix A, panel A1, we see that volatility has risen in the aftermath of the financial crisis, and this rise is not explained by the increased volatility of the market as a whole (see panel A2 and the discussion below). ${ }^{15}$ Although banks differ in their relative increases in volatility (with the most significant jumps for Bank of America, Citigroup, and Wells Fargo, which parallels the beta results described below), all six of our major banks have experienced some increase in volatility in the postcrisis period.

It is perhaps more sensible, however, to compare volatility in 2015 with volatility in the precrisis period. If it is the case that it took time for capital to accumulate and the market to grasp the implications of the new wave of financial reforms; or if in 2010 the effects of the crisis were still weighing heavily on the financial sector, then perhaps we should not be surprised that we see elevated volatility in the postcrisis period. Consistent with this hypothesis, volatility has been falling in the aftermath of the Great Recession, and the most recent average (20.67) is substantially below the precrisis estimate of 24.70 . Note, however, that the most recent volatility measure for Bank of America (23.21) remains substantially above the precrisis estimate of 19.70 .

The average Tier 1 capital ratio for the Big 6 banks has risen from 8.4 percent precrisis to 13.3 percent postcrisis, so the inverse capital ratio (1/e) discussed above has fallen from 11.9 to 7.5 . Average volatility for the Big 6 in the precrisis period is 24.70. Thus, we would expect average volatility in the postcrisis period (after Tier 1 ratios have increased) to be 15.60. This is not what we observe. Volatility is still significantly higher in 2015 (Big 6 average of 20.67) than we would have predicted given the capital increases of these large banks.

15. In the appendix tables, we also include a weighted mean (which is the average for our risk measures weighted by banks' market capitalization). Focusing on the weighted mean rather than the raw mean does not meaningfully change our results. The online appendixes for this and all other papers in this volume may be found at the Brookings Papers web page, www.brookings.edu/bpea, under "Past BPEA Editions." 
One possible explanation for our volatility results is that we are capturing changes in market volatility. That is, it is possible that bank volatility has not moved much, despite increases in capital requirements, but bank volatility relative to market volatility reflects greater stability in the financial sector. This possibility explains why beta, which is a measure of volatility with respect to the market, is perhaps a more meaningful risk measure for our analysis.

If market volatility has increased but bank volatility has remained constant, then we would expect that when we net out the market effect, we should see a decrease in volatility. We test this hypothesis in appendix A, panel A2, by dividing bank volatility by the volatility of the S\&P 500 . We see that 2015 relative volatility is actually significantly higher than relative volatility in the precrisis period-Big 6 banks were on average 1.55 times as volatile as the market before the crisis; now they are 1.78 times as volatile.

\section{III.B. Implied Volatility}

Like historical volatility, we anticipate that future volatility, as implied by option prices, will decrease as a result of heightened bank regulations, and particularly higher capital requirements. We find this too is not the case. In appendix A, panel A3, we see that implied volatility increases for all the Big 6 banks in the postcrisis period. Unfortunately, our implied volatility data are available beginning only in 2005 , so we are not fully able to compare the precrisis and postcrisis periods. Again, given the fact that (i) capital took time to accumulate, and (ii) 2010 was still fairly close to the financial crisis's conclusion, it is more sensible to benchmark against the most recent measure. When we compare 2005-07 with the most recently available 2015 implied volatility data, we see that implied volatility has barely changed, moving from a precrisis average of 22.90 to a 2015 average of 22.96 .

In appendix A, panel A4, we divide bank volatility by the VIX, which provides a measure of the implied volatility of S\&P 500 index options. ${ }^{16}$ Relative to the market, implied volatility has fallen when compared with the precrisis measure, from an average of 1.91 in the precrisis period to 1.61 in 2015. However, this decrease is much smaller than what standard theory would have predicted. Based on the corresponding increase in capitalization, we should have seen bank implied volatility divided by market

16. The results are similar when we subtract market volatility instead of dividing by it, and are available upon request. 
volatility fall from 1.91 precrisis to 1.20 postcrisis. The actual drop was of less than half this magnitude.

Volatility provides us with a crude proxy for a firm's susceptibility to bankruptcy. The implication of our volatility results is that default risk has not meaningfully changed in the postcrisis period relative to the precrisis period. Specifically, in both the precrisis and postcrisis periods, our banks appear to be about a 5-sigma move away from default in the next year (based on implied volatility estimates).

\section{III.C. Out-of-the-Money Put Option Delta}

To get a proxy for the likelihood of a major drop in stock prices, we took the delta of a deep OTM option with one year to expiration.

If the financial system has become far safer, then we would expect the probability of major declines in stock prices to have fallen since the Great Recession. ${ }^{17}$ Appendix A, panel A5, makes clear that this is not the case. Before the crisis, the probability of a 50 percent fall in stock price in the next year was around 3.6 percent. In the postcrisis era, this has increased to an average of 7.4 percent. Deltas have fallen since the peak of the crisis, suggesting that the more stringent regulatory requirements are having an impact on market assessments of the likelihood of financial sector crashes; however, even comparing the most recent measure with the precrisis period, deltas remain elevated; the most recent value is 4.6 percent-relative to the precrisis mean of 3.6 percent.

These probabilities refer to the chance of a 50 percent decline over exactly one year. Option theory suggests that the probability of at least a 50 percent decline at some point within the year is much higher. And there is the further point that the chance of a large decline over a period of several years is of course much greater.

\section{III.D. Beta}

We also look to beta to help us understand how bank risk has evolved. Using the logic of Baker and Wurgler (2015), we hypothesize that the decrease in leverage as a result of Dodd-Frank and other regulatory changes implemented in the aftermath of the crisis should have lowered bank betas. We know that this relationship between beta and leverage holds true in the cross section for our banks. However, in appendix A, panel A6, we see that for each of the Big 6 banks, beta has actually increased in the

17. As with CDS spreads (discussed below), it is important to keep in mind that these are risk-neutral probabilities and not objective measures (Sinclair 2010). 
aftermath of the Great Recession. And this increase is not a by-product of the "early" postcrisis period, before the impact of increased regulation was fully realized. Although bank betas have been falling since the crisis, they have yet to dip below precrisis levels. In fact, average beta today for these banks is 1.23 , slightly above the precrisis estimate of 1.18 . For half the Big 6 (Bank of America, Citigroup, and Wells Fargo), 2015 beta remains above the precrisis estimate.

To understand how these bank betas differ from our expectations, it is helpful to recall Baker and Wurgler (2015), who note that the relationship between leverage and beta is given by

$$
\beta_{e}=\frac{1}{e} \beta_{a} .
$$

For our domestic data, taking the average equity beta for the Big 6 in the precrisis period (1.18) based on the decrease in leverage, we can impute that our average beta in the postcrisis period should have fallen to approximately 0.75 . This is clearly not what we observe, as in 2015 average beta was 1.18 .

\section{III.E. Credit Default Swap Spread}

CDS spreads reflect the cost of insurance against a default. Hence, all else equal, CDS spreads should fall as risk (and thus the probability of default) falls. ${ }^{18}$

However, we find that CDS spreads have risen significantly in the aftermath of the crisis (appendix A, panel A7). Although the CDS spread for the S\&P 500 has increased as well, the spread increase for each of the Big 6 firms is of a significantly higher magnitude. This increase is most pronounced for Bank of America and Citigroup. Even focusing on the most recent 2015 measure (rather than the postcrisis period), to allow for the impact of increased capital accumulation to be reflected in CDS spreads, these spreads today remain about three times higher than they were in the precrisis period.

Note, however, that it is not clear how we should think about CDS spreads in the context of concerns about banks being too big to fail

18. It is worth noting that CDS spreads reflect risk-neutral probabilities, so we should be careful when we suggest that we can infer the probability of a bank's likelihood of default from its CDS spread. While the objective likelihood of default is lower than the probability implied by the CDS spread, the risk-neutral probability reflects the fact that any default will occur in a high marginal utility state. 
(TBTF) and the evolution of the government's bailout regime. It is possible that CDS spreads have risen because, although firms are better capitalized, they are less likely to be bailed out—and thus the probability of default has actually increased. This is how some in the regulatory community, including Janet Yellen (2016), have interpreted our results. We would still hypothesize that CDS spreads should have decreased as leverage decreased; however, we note that option-based estimates of the probability of a large decline in stock prices are perhaps better measures of risk because they do not depend on how the bailout regime has evolved.

\section{III.F. Price-Earnings Ratio}

Rajan (2005), in his contemplation of whether financial development had in fact made the world riskier, presents as evidence for his thesis the fact that the PE ratios of banks in the United States relative to the market had declined since the 1980s. We perform this same analysis on a different period, looking to see (in appendix A, panel A8) how our Big $6 \mathrm{PE}$ ratios (relative to the S\&P $500 \mathrm{PE}$ ratio) have evolved since the precrisis period. While the existence of the financial crisis and periods of incredibly low earnings make these figures rather difficult to interpret, the overall picture for the Big 6 suggests that relative PE ratios have moved around very little since before the Great Recession (the mean in the precrisis period was 0.67 , almost exactly equal to the postcrisis mean of 0.68 ).

For half the Big 6 (Citigroup, JPMorgan Chase, and Wells Fargo), relative $\mathrm{PE}$ ratios have decreased since the precrisis period, with the largest decrease for JPMorgan Chase, which went from a PE ratio of 0.83 before the crisis to 0.53 in 2015. The decline in relative PE ratios for these banks implies that the market is discounting earnings with an increasing risk premium over time. ${ }^{19}$ Given the new regulatory environment postcrisis and regulators' strong belief that the system is safer and better capitalized today than it was before the Great Recession, this is a surprising result, but is consistent with our other findings.

\section{III.G. Preferred Stock Price and Yields}

Another test to ascertain whether bank risk has moved in the aftermath of the Great Recession involves examining the prices of preferred shares.

19. Rajan (2005) describes the relationship between PE ratios and market risk premiums in detail. 
Since our banks have very little preferred stock, any event that causes losses to preferreds should also cause losses to debt holders. ${ }^{20}$

Thus, the risk premium on preferred stock and its evolution over time will shed light on the likelihood of a bank defaulting. Since preferred stock is unlikely to be bailed out (and, indeed, preferred stockholders suffered losses during the Great Recession), by looking at preferred stock pricing we are able to home in on the market's assessment of the likelihood of an event that absent a bailout would affect debt securities.

The price of a security is inversely related to its required rate of return. The required rate of return, in turn, is a function of (i) the riskless rate and (ii) the product of a bank's beta and the market risk premium. Barring any change in the riskiness of banks, since the riskless rate has declined substantially in the postcrisis period, we would have expected the required rate of return to have declined as well. Thus, we anticipate that the price of our preferred shares would have increased substantially in the postcrisis period. If bank betas had declined, as our theory on the relationship between beta and leverage predicted, we would have expected the required rate of return to be even lower (and, thus, for prices to be even higher) for preferred stock in the postcrisis relative to the precrisis periods.

There are two kinds of preferred stock: (i) floating-rate preferreds, whose dividends are indexed against LIBOR; and (ii) fixed-rate preferreds, which pay, as their name implies, a fixed rate annually. We focus our analysis on the precrisis relative to postcrisis prices of floating-rate preferreds. ${ }^{21}$ The fact that prices of preferred stock are lower today than they were in the precrisis period suggests that the market views banks as riskier postcrisis.

We turn to salient examples to illustrate this point in figure 3. Bank of America, Goldman Sachs, and Morgan Stanley all have floating-rate preferred shares that were first issued before the crisis period. As such, we can examine the pricing of these shares over time to learn about how the risk profiles of these banks have evolved. ${ }^{22}$

20. Since 2000, preferred stock for our Big 6 banks has averaged on the low end 4.9 percent (Citigroup) and on the high end only 10 percent (Bank of America, Morgan Stanley) of total equity.

21. The problem with looking at long-lived fixed rate preferred stock is that prices are constrained by the fact that dividends are paying a fixed rate. That is, since the dividend cannot adjust given changes in market conditions, price does not move too far from par value for these securities.

22. Note that we use these three banks as examples because of limitations of the data. Our other three large banks (Citigroup, JPMorgan Chase, and Wells Fargo) do not have floating-rate preferreds that date back to the precrisis period. 
Figure 3. Floating-Rate Preferred Stock Prices, 2006-16

Bank of America (Series E)

Closing price

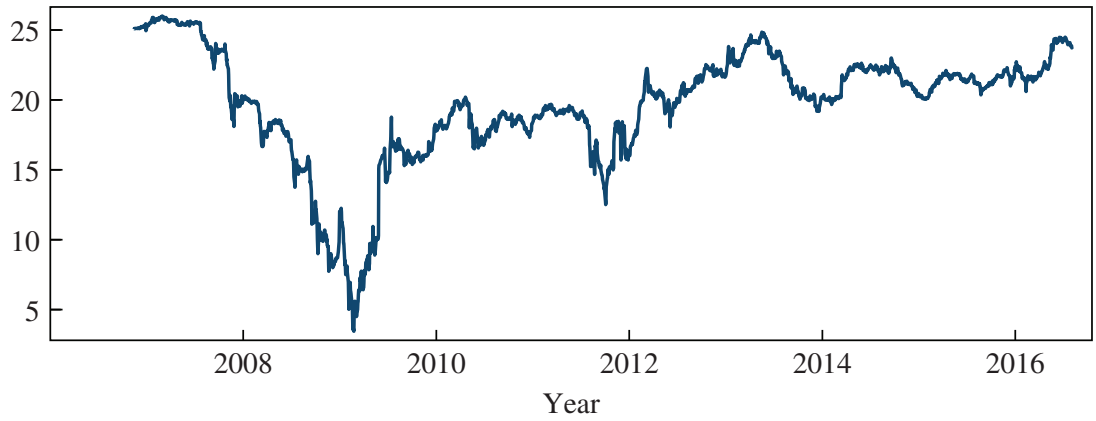

Goldman Sachs (Series D)

Closing price

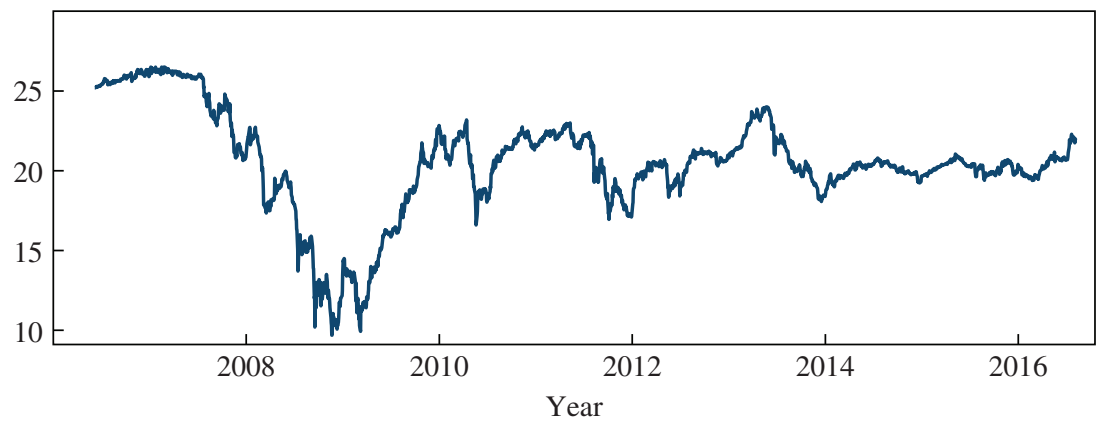

Morgan Stanley (Series A)

Closing price

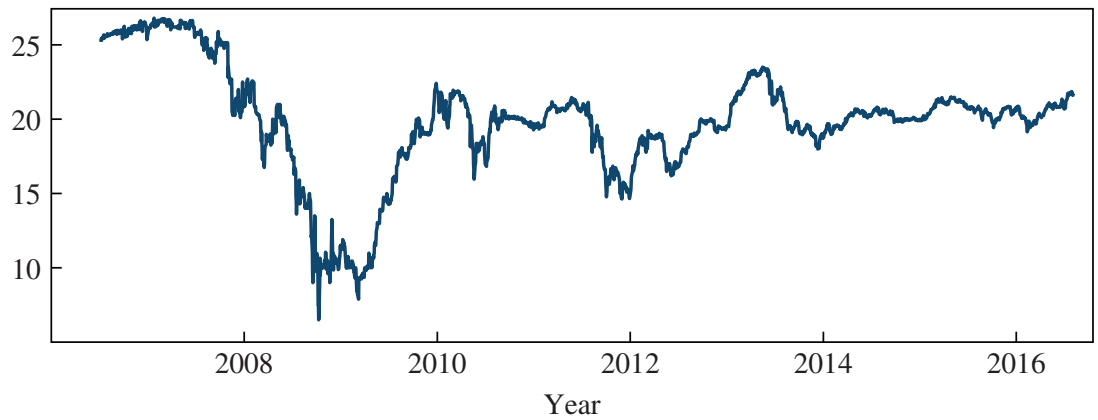

Source: New York Stock Exchange's online database. 
Table 2. Recent Preferred Stock Issuances by the Big 6 U.S. Banks ${ }^{a}$

\begin{tabular}{llccc} 
Bank & $\begin{array}{c}\text { Date of most } \\
\text { recent issue }\end{array}$ & $\begin{array}{c}\text { Par } \\
\text { value }\end{array}$ & $\begin{array}{c}\text { Current } \\
\text { price }\end{array}$ & $\begin{array}{c}\text { Current yield } \\
\text { (percent) }\end{array}$ \\
\hline Bank of America & April 2016 & $\$ 25$ & $\$ 26.60$ & 5.64 \\
Citigroup & January 2016 & $\$ 25$ & $\$ 27.12$ & 5.81 \\
Goldman Sachs & April 2016 & $\$ 25$ & $\$ 27.48$ & 5.73 \\
JPMorgan Chase & April 2014 & $\$ 25$ & $\$ 27.49$ & 5.73 \\
Morgan Stanley & April 2014 & $\$ 25$ & $\$ 27.59$ & 6.00 \\
Wells Fargo & June 2016 & $\$ 25$ & $\$ 26.91$ & 5.11 \\
\hline
\end{tabular}

Source: New York Stock Exchange's online database.

a. For all banks except Morgan Stanley, yields are for recently issued fixed-rate preferreds. Morgan Stanley issued a fixed-rate preferred with a 5.375 percent annual yield that will convert to a floating rate in five years.

For Bank of America, we look at Series E preferreds, which started trading in 2006 and pay a rate per year equal to the greater of the three-month LIBOR plus 0.35 percent or 4.00 percent per annum; for Goldman Sachs, we look at Series D preferreds, which became available in 2005 and which pay the greater of 0.67 percent above LIBOR or a minimum of 4.00 percent; and for Morgan Stanley, we look at Series A preferreds, which pay the greater of the three-month LIBOR plus 0.70 percent, or 4.00 percent. In all three cases, we see that the average price for these shares in the precrisis period (2007 and prior) is higher than the postcrisis price (24.26 versus 20.11 for Bank of America; 25.12 versus 20.66 for Goldman Sachs; and 25.36 versus 19.68 for Morgan Stanley). And while these preferreds have rebounded slightly since the Great Recession, prices in the last year have remained lower than they were in the precrisis period for all three securities.

Since the risk-free rate has declined so much in this period, with a decrease in bank risk - or even with the same level of risk as in the precrisis period-preferred prices should be higher today than they were before the crisis. The fact that we see a decrease in the prices of these preferreds suggests that the market's assessment of risk, at least for these banks, has increased over the same period that riskless rates have fallen.

Note that the existence of long-lived preferred stocks that date back to the precrisis period is, in and of itself, a significant finding for our analysis. That is, we would anticipate that since interest rates decreased significantly, if bank risk stayed the same (or even declined), then Bank of America, Goldman Sachs, and Morgan Stanley would have been able to call these securities and issue replacement stock at a much lower yield.

A version of this same point can be made by looking at more recent preferred stock issuances by our Big 6 banks. As we see in table 2, in 2016 
alone, Bank of America issued a preferred share that is currently yielding 5.64 percent, Citigroup issued a preferred share that is yielding 5.81 percent, Goldman Sachs issued a preferred share that is yielding 5.73 percent, and Wells Fargo issued a preferred share that is yielding 5.11 percent. The fact that most preferred stock recently issued by these banks is yielding between 5 and 6 percent suggests that these banks are far from safe, and that the holders of bank preferreds demand substantial compensation for bearing risk.

\section{III.H. Systemic Risk Contribution}

Using Acharya and others' (2017) systemic risk measure, we can ascertain how each firm's contribution to systemic risk has evolved in the aftermath of the financial crisis. This measure is of special interest because it has been demonstrated to have predictive power in a crisis when other measures have been lacking. We see in appendix A, panel A10, that the contribution of four of the six firms (Bank of America, Citigroup, JPMorgan Chase, and Wells Fargo) to systemic risk has increased in the postcrisis period; while the relative contribution of Goldman Sachs and Morgan Stanley has declined. As a group, the systemic risk contribution of the Big 6 has nearly doubled. Although systemic risk contribution peaked in 2011, it remains elevated relative to precrisis levels today.

\section{III.I. Understanding These Measures}

Our measures allow us to capture changes in bank risk based on different assumptions. The most basic volatility measures-historical and implied volatility and beta-provide a baseline assessment of how risk has evolved in the aftermath of the crisis. However, if banks are safer today because they will be forced into dilutive equity issuances in times of distress, it is possible that equity volatility may in fact have increased in the recent epoch. So, volatility, which captures risk to equity holders, does not provide a full assessment of the evolution of financial sector soundness as a result of postcrisis reforms. Said another way, reforms that have made the financial system more stable could well have increased equity volatility.

In contrast, CDS spreads, which provide a price of insurance against bank default, will decline if the likelihood of a destabilizing financial event is unchanged (or perhaps, even increased, postcrisis), but simultaneously the likelihood that banks will be forced to raise new equity before failing has increased. As such, although beta and volatility may increase if banks 
are now forced into dilutive equity issuances in times of distress, we should see CDS spreads decline.

However, CDS spreads will also capture the likelihood of a government bailout. Even if CDS spreads remain elevated, some may argue (and in fact, some, including Janet Yellen, have interpreted our results as suggesting) that CDS spreads are high because the likelihood of a government bailout in a post-Dodd-Frank world is drastically decreased (Yellen 2016). Some empirical work has been done to establish a decline in the so-called "too-big-to-fail subsidy." ${ }^{23}$ Our CDS results are vulnerable to the criticism that they remain inflated postcrisis because the TBTF subsidy has disappeared.

For this reason, we also look to preferred stock pricing before and after the Great Recession. Preferred stock, like CDS spreads, is affected by changes in banks' likelihood of raising equity in dire times. However, preferred stock is not affected by the presence of a TBTF subsidy in the same way as CDS spreads, as preferred stock is a thin layer of equity that sits right below debt in a bank's capital structure. This means that preferred stock can-and during the financial crisis, did-experience losses, even though debt was bailed out. ${ }^{24}$ As such, our preferred stock results are not susceptible to the critique that they are impacted by changes in the probability of a government bailout in the aftermath of the crisis and the regulatory reforms that it precipitated.

Taking all the findings together, it appears that markets are not treating large banks today as less levered and more safe than they were treating them before the financial crisis. While it is possible that the greater likelihood of dilutive equity issues accounts in part for the failure of volatility and beta to decline, on this view there should have been, contrary to observation, a major decline in CDS spreads and in preferred stock yields.

We next consider midsize domestic banks and international banks. Our results in both cases are similar to those we find for the Big 6 U.S. banks.

23. See, for example, Konczal (2015b), citing two different quantitative approaches that suggest the subsidy has declined. The U.S. Government Accountability Office uses a crosssectional approach, comparing TBTF banks to non-TBTF banks, controlling for other characteristics, and concludes that while a subsidy existed precrisis it has basically fallen to zero. And the IMF uses a time-series approach, comparing TBTF banks precrisis and postcrisis to come to the same conclusion. We think more work is necessary to understand the magnitude of this decline, as Baker (2015) and Konczal (2015a) himself suggest.

24. As an example, Citigroup significantly diluted the value of its preferred shares during the crisis (Dash 2009). 


\section{Midsize Domestic Banks}

We next extend our results to the largest banks in the United States outside the Big 6. We focus on the next 50 largest banks (those ranked 7 to 56 in terms of market capitalization, by 2015 assets). ${ }^{25}$ These 50 midsize banks differ vastly in size-with 2015 market capitalization ranging from over $\$ 78$ billion (American Express) to barely over $\$ 2$ billion (EverBank).

We include data for the subset of banks for which we are able to compile information on our risk measures, including bank betas, volatility, implied volatility, and CDS spreads. This requires that we exclude those large banks that are not publicly traded and that are subsidiaries of other publicly traded institutions (for example, GE Capital). In our analysis, we present results for these midsize banks by quintile, sorting them into groups depending on their average market capitalization in the precrisis, postcrisis, and 2015 periods in turn. While most banks remain in the same quintile for these three distinct periods, some shift quintiles at different moments. (For example, Silicon Valley Bank is in the second quintile in the postcrisis period, with an average market capitalization of around $\$ 3.3$ billion, and in the third quintile in 2015 , with an average market capitalization of around $\$ 6.6$ billion.)

Our findings outside the Big 6, presented in appendix B, are largely consistent with our prior results. We see that volatility (panel B1) has decreased when we compare the precrisis averages with the most recent 2015 measures. When we divide by market volatility (panel B2), we see that volatility actually remains higher in 2015 than in the precrisis period. On many measures, it appears that large banks have had less reduction in risk in the postcrisis period than their smaller counterparts, suggesting that at least to a certain extent, regulation aimed at lessening the risk of large, systemically important banks is having the intended effect.

For example, appendix B, panel B5, compares the betas of midsize banks in the precrisis period with the 2015 measure, and we see that for the smallest banks (those in the bottom three quintiles), beta is substantially higher in 2015 than it was in the precrisis period. For banks in the top two quintiles, beta has not moved much.

25. Note that we choose for our sample the 50 largest banks by 2015 assets, so our results suffer from survivorship bias. This likely biases our results downward. Since bank risk strategies are persistent, we believe that the failed banks would have likely had higher risk measures in 2015 compared with those of an average survivor bank in the sample. For a discussion of persistence, see Fahlenbrach, Prilmeier, and Stulz (2012), who find that those banks that did worst in the 1998 crisis were most likely to fail during the Great Recession. 
We can impute expected volatility and beta based on changes in leverage to give us a benchmark against which to measure the changes we observe. Outside the Big 6, Tier 1 capital ratios for these midsize banks increased from the precrisis to postcrisis periods, from 10.3 to 13.4 percent. Precrisis historical and implied volatility (for banks in all quintiles) averaged slightly above 25.5 for both our measures, and thus we would predict that volatility and implied volatility should have fallen to around 19.7. Historical volatility remains above this, at 21.61; and implied volatility has actually increased since the precrisis period, to an average of 26.79 in 2015. And although Tier 1 ratios have increased by an average of 30 percent, betas have actually risen, from 0.96 to 1.05 on average in 2015 .

\section{International Results}

To supplement our main findings and in efforts to understand how bank risk has evolved for systemically important banks across the globe, we next move to looking at the same risk measures documented above for large international banks.

We begin by considering the 50 largest banks in the world (ranked by market capitalization). After excluding U.S. and Chinese banks, ${ }^{26}$ and banks for which we do not have information on betas, volatility, implied volatility, CDS spreads, and price-to-book ratios, ${ }^{27}$ we are left with a sample of 30 international banks. Rather than reporting individual bank averages for the 30 international banks in our sample, we group the banks by country and report country averages in appendix C. ${ }^{28}$ This allows us to ascertain if banks in specific countries are driving the results that we document.

Our findings for international banks are broadly consistent with those for the Big 6 and midsize domestic banks reported above. Our results

26. We exclude Chinese banks because state ownership involves different issues than the ones we are focused on.

27. We are not able to collect reliable options data for our international banks to impute option deltas.

28. Australian banks include Australia and New Zealand Banking Group, National Australia Bank, and Westpac. The Brazilian bank in our sample is Banco do Brasil. Canadian banks include Bank of Montreal, Royal Bank of Canada, Scotiabank, and Toronto-Dominion Bank. Danske is the Danish bank in our sample and ING is the Dutch bank. French banks are BNP Paribas, Crédit Agricole, Natixis, and Sociéte Générale. German banks are Commerzbank and Deutsche Bank. Italian banks are Banca Intesa Sanpaolo and UniCredit. Japanese banks are Mitsubishi, Mizuho, and Sumitomo. Santander is the Spanish bank in our sample. Nordea is the Swedish bank in our sample. Credit Suisse and UBS are the Swiss banks. The U.K. banks are Barclays, HSBC, Lloyds Bank, Royal Bank of Scotland, and Standard Chartered. 
for volatility (appendix C, panel C1) and implied volatility (appendix C, panel C3) are more striking than our domestic findings. Our results outside the United States reflect roughly no change in volatility from the precrisis to postcrisis periods. Again, our results are not driven by the fact that (i) the postcrisis period includes 2010, when crisis shockwaves were still being felt; or (ii) the impact of the new regulatory regime took time to be felt in international banks. Average volatility for international banks in 2015 was 25.57, very similar to the precrisis average of 26.55 .

And, as is the case for midsize U.S. banks, implied volatility for international banks actually increased (from an average of 22.10 precrisis to 27.27 in 2015). This increase is concentrated in Italy, the Netherlands, and Spain. Although implied volatility relative to the home market indexes has decreased on average, banks in these three countries have seen their implied volatility increase relative to the market (appendix C, panel C4). ${ }^{29}$

Our results for international bank betas are similar to these volatility results. Bank betas have risen (appendix C, panel C5), not fallen, in the aftermath of the Great Recession, and this rise is even more pronounced for international banks (which had a precrisis average beta of 0.80 and a 2015 beta of 0.99) than it is for the Big 6 U.S. banks (which had a precrisis average beta of 1.18 and a 2015 beta of 1.23). This increase in beta is particularly pronounced for banks in Australia, Brazil, Canada, Denmark, France, Italy, and Sweden. Only Swiss banks have seen a substantial decline in beta since 2002, and most other countries have seen betas rise, except Japan and the United Kingdom, where betas have roughly stayed the same.

CDS data are far from complete for international banks, and many are missing data for both the precrisis and postcrisis periods. For the few data points we have, we see in appendix C, panel C6, that international banks have experienced an even more dramatic rise in CDS spreads relative to U.S. banks. However, this is driven substantially by the CDS spread of Banco do Brasil; when this bank is excluded from the sample, we see that the average CDS spread is 77.32 for 2015, below the Big 6 mean of 93.58 . Both domestic and international banks have substantially higher CDS spreads today than before the crisis.

It is interesting to consider these results in the context of international financial regulators' statements about the financial system. For example,

29. The same is true in Australia, although we do not have an Australian implied volatility index, and instead benchmark against the U.S. VIX. 
Mark Carney remarked in 2014 that the increase in capital requirements had made banks safer: "Banks were woefully undercapitalized-many of the largest banks were levered 40 to 50 times. They are now much more resilient" (Carney 2014). And as recently as this summer, in response to the Brexit referendum results, Carney urged calm, noting, "The capital requirements of our largest banks are now ten times higher than before the crisis... This substantial capital and huge liquidity give banks the flexibility they need to continue to lend to U.K. businesses and households, even during challenging times" (Carney 2016b).

And yet, the biggest U.K. banks (Barclays, HSBC, Lloyds Bank, Royal Bank of Scotland, and Standard Chartered), which are in our sample of large international banks, look, based on market measures, to be no safer in the postcrisis period relative to the precrisis period. CDS spreads for the large U.K. banks averaged 97.21 in 2015 relative to the precrisis average of 13.53, and implied volatility averaged 27.02 in 2015 relative to the precrisis average of 23.04. And while betas have not increased (comparing 2015 with the precrisis period), they have not decreased either, and are stuck at around 0.85 , exactly where they were before the Great Recession. It is hard to understand why, given the substantial increases in capitalization that Carney often highlights, we see no movement in our risk measures for the large U.K. institutions that were most affected by the postcrisis reforms. Given the changes in the regulatory framework-and viewed through the lens of Carney's (and others') statements on the impact of increased capital on bank stability-these are puzzling findings..$^{30}$

\section{Discussion}

The suite of measures considered in the previous sections taken together suggest to us that markets do not regard banks as substantially safer today than they were in the precrisis period.

We envision three primary explanations for our findings, which we take up in the remainder of this section. First, the market error explanation holds that markets badly underestimated the risks associated with banking prior to the financial crisis and have adjusted their views in light of painful experience. If this were the case, banks might be substantially safer today

30. See, for example, President Obama's remarks at the five-year anniversary of the financial crisis (Obama 2013); and Federal Reserve chairwoman Yellen's speech on finance and society at the Institute for New Economic Thinking (Yellen 2015), discussed above. 
than they were prior to the crisis, but the difference is obscured by the excessive optimism that prevailed prior to the crisis. Implicitly, this is the view taken by the regulatory community.

Second, the bank capital mismeasurement explanation holds that regulatory bank capital measures may be highly flawed and may even have become more flawed over time as banks arbitrage regulatory rules. Andrew Haldane has made such an argument, pointing to the great increase in regulatory complexity, the use of internal models, and declines in the ratio of risk-weighted assets to total assets (Haldane 2014). In this case, banks have not become significantly safer than they were previously because regulation has been circumvented.

Third, the declining franchise value explanation recognizes that while, ceteris paribus, banks have become safer because of higher capital requirements, other developments have eroded their franchise value, thus increasing their effective leverage and riskiness. This hypothesis, which we find most plausible and important for explaining our findings, is suggested by very substantial declines in the price-to-book ratios and the ratios of market value of equity to assets for most major banks, and by international comparisons.

\section{VI.A. Market Misperception of Risk}

One possible explanation for our findings is that in the precrisis period, the market failed to fully internalize the risks inherent in the financial sector. The dismal returns earned by investors in the financial sector during the crisis period demonstrate that this must have been the case to some extent.

Testifying before the House Committee on Financial Services in September 2016, Janet Yellen argued in favor of this hypothesis, suggesting that one explanation for our results was that "prior to the crisis, clearly market participants underestimated risks" (Yellen 2016).

Relatedly, many have pointed out that the precrisis period we use (2002-07) was one in which beta and volatility were deflated, perhaps because the market misunderstood risks in the financial sector (Konczal 2016). This could be related to the precrisis period being a bubble, as there is a well known tendency for stock price levels and volatility to vary inversely, perhaps because higher market levels mean less leverage on a market-value basis. ${ }^{31}$

31. Though if bank stock prices contain a "bubble component," this might be expected to add to volatility. 
Table 3. Beta, Volatility, and Ratio of Bank Volatility to Market Volatility for the Big 6 U.S. Banks

\begin{tabular}{lcccc}
\hline Bank & $1995-2005$ & $2002-07$ & Postcrisis & 2015 \\
\hline Beta & & & & \\
Bank of America & 1.09 & 0.88 & 1.79 & 1.22 \\
Citigroup & 1.48 & 1.19 & 1.78 & 1.32 \\
Goldman Sachs & 1.24 & 1.33 & 1.32 & 1.21 \\
JPMorgan Chase & 1.39 & 1.35 & 1.46 & 1.20 \\
Morgan Stanley & 1.63 & 1.56 & 1.85 & 1.40 \\
Wells Fargo & 0.97 & 0.77 & 1.43 & 1.04 \\
Mean & 1.30 & 1.18 & 1.61 & 1.23 \\
Median & 1.32 & 1.18 & 1.49 & 1.22 \\
Volatility & & & & \\
Bank of America & 29.54 & 19.70 & 39.02 & 23.21 \\
Citigroup & 34.19 & 24.51 & 38.06 & 21.75 \\
Goldman Sachs & 36.71 & 26.92 & 28.23 & 19.35 \\
JPMorgan Chase & 34.78 & 28.01 & 29.57 & 20.17 \\
Morgan Stanley & 40.60 & 31.75 & 37.22 & 22.60 \\
Wells Fargo & 26.29 & 17.29 & 28.74 & 16.94 \\
Mean & 33.69 & 24.70 & 33.47 & 20.67 \\
Median & 34.49 & 25.71 & 33.40 & 20.96 \\
\hline
\end{tabular}

Source: Bloomberg.

We examine the market error hypothesis by comparing recent bank risk measures with the period 1995-2005. We present these results in table 3. It does appear, as Mike Konczal (2016) notes, that beta and volatility were low in the years leading up to the financial crisis, providing evidence that the precrisis bubble explains our findings, at least to some degree. However, relative to the postcrisis period, even the earlier 1995-2005 era had a lower beta (1.30 on average for the Big 6, relative to 1.61 postcrisis) and basically equivalent volatility ( 33.69 , relative to 33.47 postcrisis). The average Tier 1 ratio in this extended precrisis period was 8.2 percent, very similar to the 2002-07 average of 8.4 percent. As such, we would expect to find average volatility in 2015 to be significantly lower (around 15) than what we observe (Big 6 average of nearly 21). As such, although the few years prior to the crisis were a bubble period that deflated betas and volatility relative to longer-term averages, we believe this deflation alone cannot explain our findings.

It is easy to understand why excessive optimism about financial stability could have led to the overpricing of bank securities before the crisis. It is 
much less clear why it should have led to their being insufficiently volatile in response to daily news. If prior to the crisis there was a tendency for bank stock prices to underreact to news, one would expect to see some evidence of positive serial correlation as underreactions were eventually corrected. One would expect this tendency to diminish or be eliminated in the postcrisis period.

We follow James Poterba and Summers (1988) and Andrew Lo and Craig MacKinlay (1989) in computing variance ratios to test for autocorrelation in bank stock returns during the precrisis and postcrisis periods. To compute variance ratios, we begin with daily price data and compute (i) daily returns; (ii) 5-day returns (for nonoverlapping 5-day intervals); (iii) 10-day returns (for nonoverlapping 10-day intervals); (iv) 20-day returns (for nonoverlapping 20-day intervals); and (v) 50-day returns (for nonoverlapping 50-day intervals).

We then compute the variance of returns in each of these samples both before and after the crisis and take the ratio of the variance for each interval relative to the variance of our daily (log) returns. Our goal is to ascertain whether (i) there is evidence of a positive autocorrelation in the precrisis period; and (ii) there is more positive autocorrelation in the precrisis period relative to the postcrisis period (which would be an argument in favor of the market error hypothesis).

We report results in table 4 only for the Big 6 banks; however, these results are comparable for the rest of the large U.S. banks and are available upon request.

Variance ratios for the Big 6 banks provide no support for the view that there is a significant positive serial correlation in returns during the precrisis period. Variance ratios are generally less than horizon length, suggesting a modest negative rather than positive autocorrelation.

As a final bit of evidence on the market error theory, we look to analysts' estimates of future bank earnings in the United States in the precrisis and postcrisis periods. If beta and volatility were low in the precrisis period because the market failed to understand the risks banks faced, then we would anticipate that analysts' forecasts would be more accurate in the postcrisis period (when markets have a better understanding of financial sector risks).

We test this theory directly by using data from the Thomson Reuters Institutional Brokers' Estimate System (I/B/E/S). We pull all quarterly analyst forecasts for our largest U.S. banks (both the Big 6 and midsize banks) made from 2002 to 2015 . We then measure average deviation from actual 


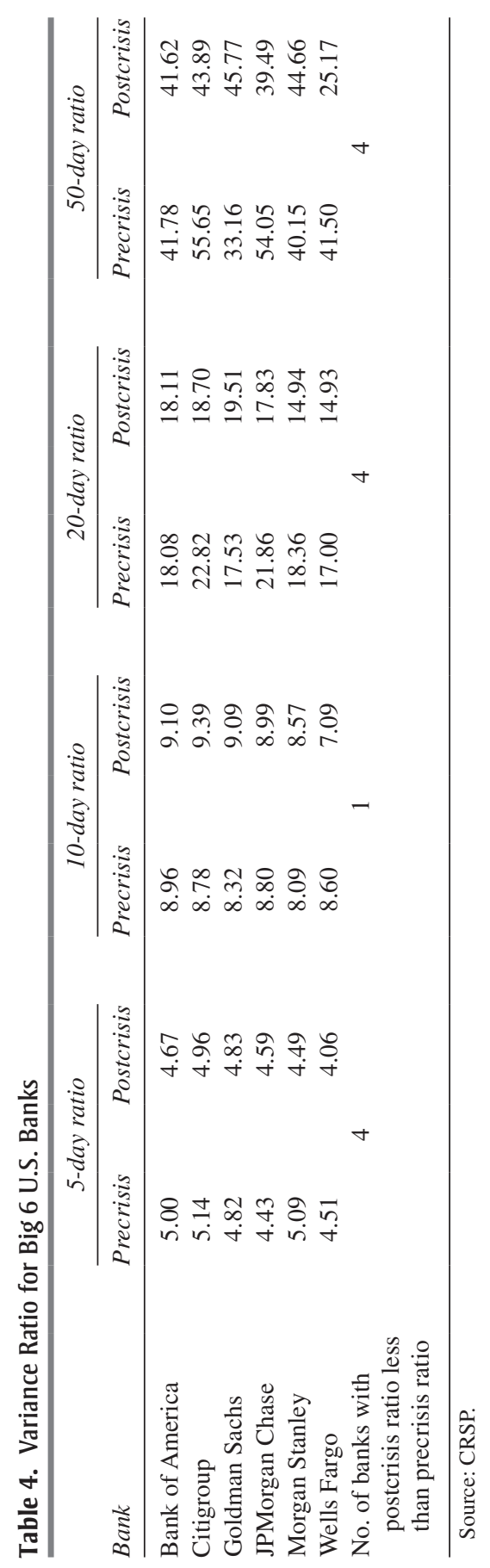


Table 5. $t$ Test for Difference in Means in Analyst Report Deviations for U.S. Banks

\begin{tabular}{lcc}
\hline Indicator & Precrisis & Postcrisis \\
\hline Deviation from earnings per share & -0.0082 & $0.0377^{* * * *}$ \\
& $(0.1848)$ & $(0.4643)$ \\
Absolute value of deviation from earnings per share & 0.0516 & $0.1166^{* * *}$ \\
& $(0.1776)$ & $(0.4511)$ \\
Deviation from earnings-price ratio & -0.0001 & $0.0007^{* * *}$ \\
& $(0.0049)$ & $(0.0065)$ \\
Absolute value of deviation from earnings-price ratio & 0.0015 & $0.0028^{* * *}$ \\
& $(0.0047)$ & $(0.0059)$
\end{tabular}

Sources: CRSP; Compustat; I/B/E/S.

a. Standard errors are in parentheses. Statistical significance is indicated at the $* * * 1$ percent level.

earnings and do a basic $t$ test to see if precrisis deviations differ from postcrisis deviations in a statistically significant way. ${ }^{32}$ Our results are reported in table 5. We find that precrisis deviations differ from those that analysts make postcrisis, but our results do not support market misunderstanding of risk as the explanation for these differences. We find that (i) deviations are larger (in absolute value) in the postcrisis period; and (ii) the sign of the deviations switches-specifically, that analysts are on average overly optimistic postcrisis and overly pessimistic precrisis. ${ }^{33}$

Perhaps the most important point to make regarding the market error hypothesis is of a different sort. Regardless of whether excess market complacency can or cannot explain the low level of market risk measures precrisis, current market indicators of risk are not encouraging. Table 1 notes that the average option implied probability of a 50 percent decline in stock prices for major banks is 4.6 for one year. It is 11.4 percent for four years. ${ }^{34}$ These estimates understate the risk of a major decline because they focus only on option end dates (not on the whole price path), and because

32. We measure deviation first as the ratio of earnings: average analysts' predictions (scaled by earnings plus analyst predictions to give us more sensible values). Then, we consider the absolute value of these deviations. And finally, we follow Khan, Rozenbaum, and Sadka (2013) and measure average deviation from actual earnings scaled by price on the day earnings are announced. We report $t$ tests for all three of these measures of analysts' deviations.

33. Note that we are excluding the crisis period, and in the lead-up, analysts were likely overly optimistic.

34. Results are available upon request. 
they ignore the likely tendency for the volatility of bank assets to rise as their value declines. ${ }^{35}$ As we noted in subsection III.G, the level of preferred yields also suggests grounds for concern about the health of major banks.

Ex post, there can be no question that markets were underestimating risks to the financial sector during the precrisis period and this manifested itself both in excessive valuations and depressed risk measures. We are, however, very skeptical of using this observation to dismiss the relevance of market measures in assessing bank risk. The market's errors were in our judgment both smaller and less protracted than those of regulators who dismissed concerns about the inadequacy of capital for major institutions as late as the summer of 2008 .

\section{VI.B. Bank Capital Mismeasurement}

Another possible explanation for the bank capital volatility puzzle we document is that bank capital (as calculated) is so distorted as a measure of capital in an economic sense that measures to raise regulatory capital have not in fact had a large impact on economic capital. Calculations of bank capital are very sensitive to procedures for valuing loans and other illiquid assets. John Vickers (2016, p. 80) makes this point, noting that since the capital numbers used in regulation are accounting figures, they are "themselves uncertain measures of the constantly changing underlying position." And as Haldane (2014) explains, there are also a variety of ways in which capital requirements can be gamed. Acharya, Diane Pierret, and Sascha Steffen (2016, p. 5) provide empirical support for the deficiencies of regulatory capital measures, finding that the "countries that are considered to have the safest banking sectors according to Basel risk weights (e.g., Belgium, France, and Germany) are considered to be the riskiest according to market risk weights." In earlier work, Acharya and Steffen (2014) demonstrate that there is no correlation between capital shortfalls computed using market risk measures and those that make use of regulatory risk weights. The authors worry that "static and out-of-date risk weights" cause regulators to underestimate the true capital shortfalls of major banks (Acharya and Steffen 2014, p. 3).

Bulow and Klemperer (2013) provide a further dramatic illustration of the imperfection of regulatory capital measures. They note that if the 413 banks that failed between 2008 and 2011 (when 6 percent core Tier 1

35. Think of a mortgage on a building. It will not move much with the price of the building until the building's value has declined to close to the value of the mortgage. 
equity was required to be classified as "well capitalized") had each held an additional 14 percent of assets in cash, this infusion would have covered losses for fewer than 10 percent of these failures. In other words, most failed banks are found ex post to have a capital gap of more than 14 percent of assets..$^{36}$ Lehman Brothers provides a particularly vivid example of the dangers of overreliance on regulatory capital measures - the bank was far beyond well capitalized (Tier 1 capital of 11.6 percent) immediately before its bankruptcy in September 2008. ${ }^{37}$ If regulatory capital is a sufficiently weak measure of actual capital, it is possible that the increase in Tier 1 capital as a consequence of a more stringent regulatory framework in the post-Recession period has done relatively little to stabilize the financial sector. Relatedly, it is plausible that although banks are being forced to hold more capital (and have higher Tier 1 ratios), they are finding ways to increase risk that game the current risk-weighted asset rules and the existing stress tests.

We are not sure how to evaluate this possibility. The evidence from Baker and Wurgler (2015) discussed in section I-that bank betas and capital ratios are negatively related in the cross section-suggests that there is in fact information value in capital ratios. Moreover, there is the logical point that for any given degree of error in asset valuations, holding more capital should increase safety and soundness.

In assessing volatility and riskiness of banks, it seems appropriate to look at market measures of capital which have the virtue of reflecting market assessments of the value of assets and also of being dynamic (relative to regulatory capital ratios) because they take account of banks' capacity to generate future profits. We examine such measures in the next subsection.

\section{VI.C. Declining Franchise Value}

Table 6-which provides information on banks' price-to-book ratios, price-to-tangible-book ratios, and the ratio of the market value of equity to total assets on a risk-adjusted and risk-unadjusted basis-is key to understanding our findings. ${ }^{38}$ Even though book value measures suggest that banks are much less levered than previously, the declines in market valuation of banks have been so large that measured on a market basis, banks have less equity relative to assets than they did previously.

36. In fact, IndyMac cost an amount equal to 42 percent of assets to resolve.

37. Johnson and Kwak (2010) point out that investigation into Lehman's capital position shows that this figure was inflated by "aggressive and misleading" accounting.

38. Tangible book value removes goodwill and other intangible assets such as deferred tax benefits from the basic book value measure. 


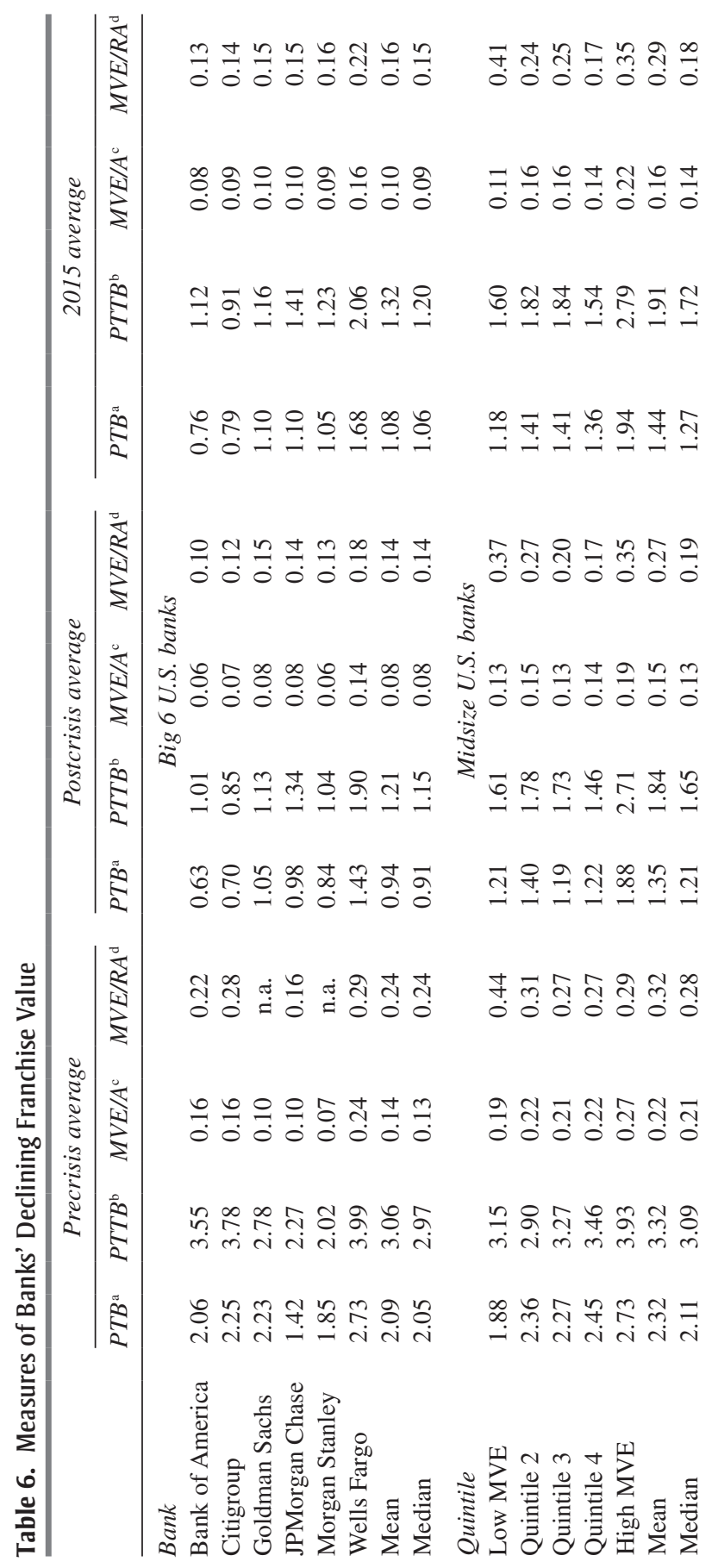




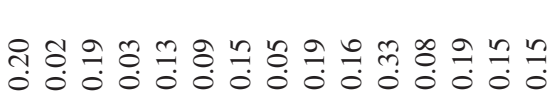

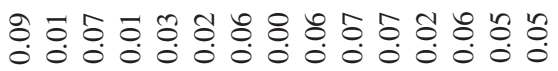

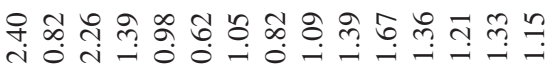

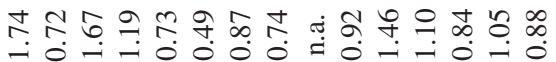

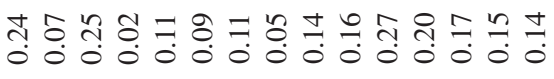

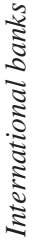

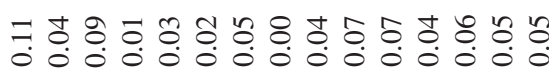

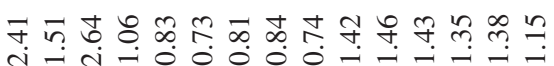

도공

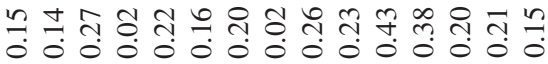

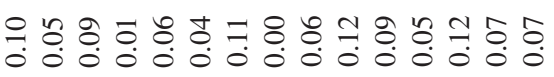

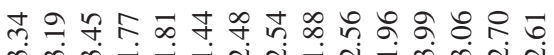

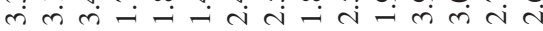

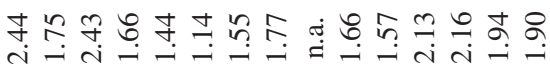

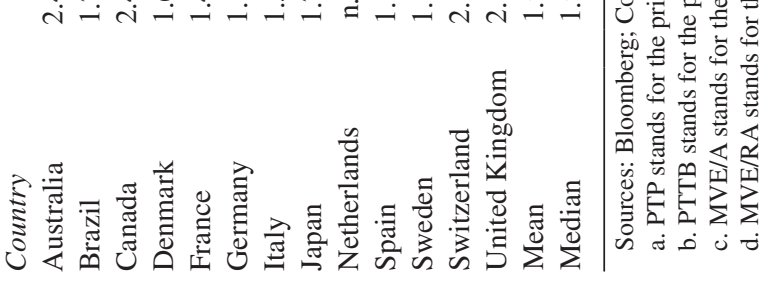


This observation rationalizes all our findings. If banks have less equity relative to their assets, they are in a sense more levered. So one would expect more volatility, a higher probability of a major stock price decline, riskier debt, higher yields on preferred stock, and higher expected returns on common stock. This is exactly what we observe.

The question then becomes why has there been so substantial a change in the market value of banks relative to their book value. In 2006, the total market value of the Big 6 U.S. banks exceeded their total book value by over 100 percent of book value, or $\$ 492$ billion. By 2015, this gap had shrunk to around 1 percent of book value, or $\$ 13.2$ billion. ${ }^{39}$ As we noted in the previous subsection, one possible explanation for the decline in priceto-book ratios is increasing mismeasurement of assets. This, in our view is unlikely to be a large part of the story. If anything, there is now more regulatory pressure to accurately value assets than prior to the crisis. And valuation errors are not a plausible explanation for price-to-book ratios far in excess of 1 and price-to-tangible-book ratios close to 3 prior to the crisis. In figure 4, we look at the trends in the ratio of market value of equity to assets, documenting the evolution of this ratio since 2000 for the Big 6 U.S. banks. While there are different patterns for each firm, it is noteworthy that for all six banks we observe a downward trend over the last 15 years. ${ }^{40}$ There has been some rallying since the Great Recession's trough; however, even today banks appear, based on this measure, more levered than they were at the turn of the century.

At first glance, this is surprising, given the increase in capital requirements as a result of postcrisis regulatory reforms. One explanation for our findings is as follows: Because of enhanced regulations and changes in macroeconomic conditions, banks have suffered losses in franchise value, which had previously served to bolster their profitability and thus the market value of their equity in the precrisis era. This franchise value was a form of capital for banks to draw upon to help absorb losses. Hence today, banks that are less profitable are effectively more levered because they have lost this buffer. This loss of capital has offset the increases in bookvalue capital achieved through regulatory changes. In some cases, the two effects are closely linked. Consider the case of banks that have sold off

39. These numbers fluctuate annually but are well below the 2006 estimate-in 2014 , the gap was 10 percent of book value, or about $\$ 92$ billion.

40. Note that these comparisons are complicated by changes in the organization of these institutions over time, for example, the merger of J.P. Morgan and Chase Manhattan Bank in 2000, and the merger of Bank of America and Merrill Lynch in 2008. 
Figure 4. The Ratio of Market Value of Equity to Assets for the Big 6 U.S. Banks, 2000-16

Bank of America

Ratio

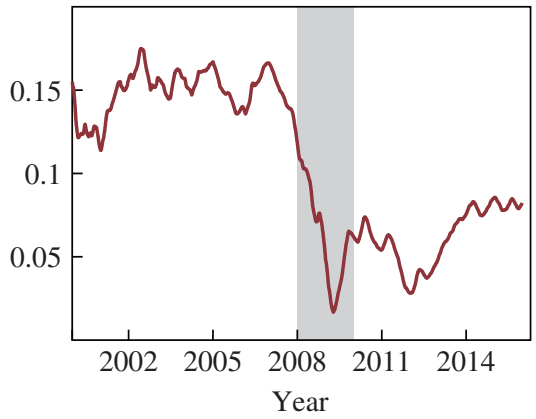

Goldman Sachs

Ratio

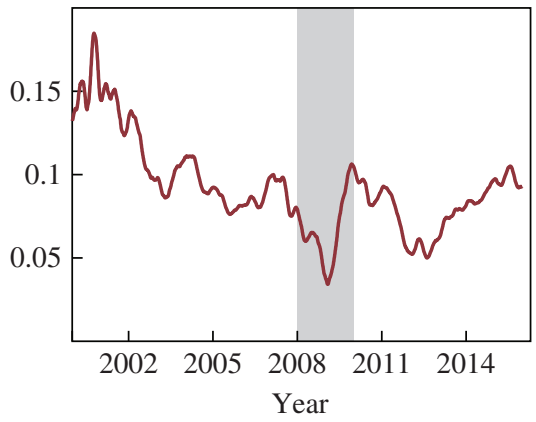

Morgan Stanley

Ratio

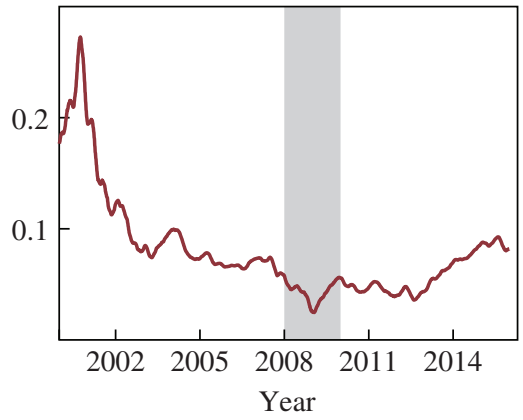

Citigroup

Ratio

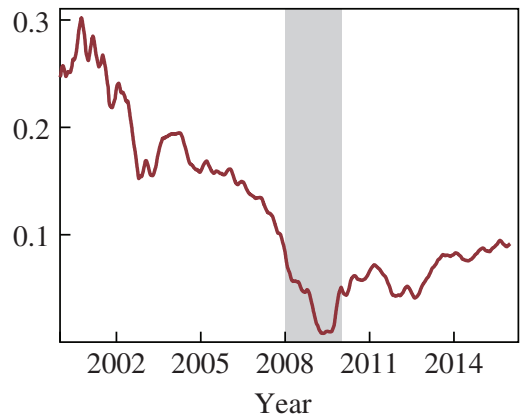

JPMorgan Chase

Ratio

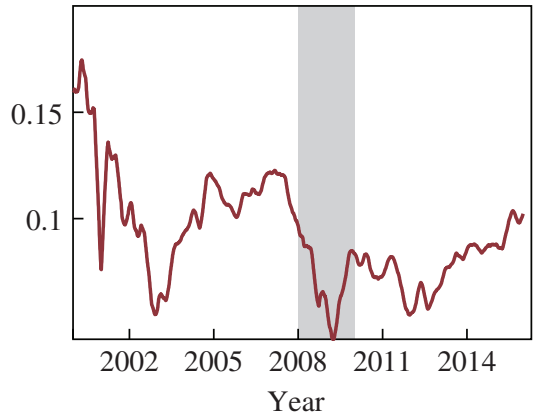

Wells Fargo

Ratio

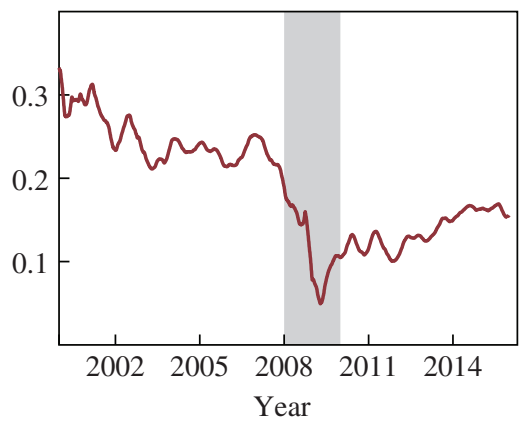

Sources: Bloomberg; CRSP.

a. The shaded regions indicate crisis years, 2008-09 in our sample. 
valuable assets to raise capital, such as when Merrill Lynch sold off its stake in Bloomberg in 2008. Measured capital went up, but a future profit stream that had been available to absorb losses disappeared.

The IMF's October 2016 Global Financial Stability Report points to "weak bank profitability ... as a looming financial stability challenge for many advanced economy banks." The report highlights that "the market's current assessment of the ability of banks to meet these challenges is not optimistic," as price-to-book ratios have fallen to levels in line with the worst points of the crisis, especially in the euro area and Japan (IMF 2016, p. 11).

A variety of factors have impinged on bank franchise values in recent years, to the point where the decline can be overexplained. These include the consequences of low interest rates and a relatively flat yield curve for bank profitability; regulatory restrictions on a range of allegedly unlawful profitable practices, from proprietary trading to credit card interchange to overdraft fees; substantial financial penalties for past practices; increased competition from shadow banks; and an overhang of likely future regulatory actions.

Charles Calomiris and Doron Nissim (2014) systematically examine declines in price-to-book ratios for a large sample of banks and reject the view that this decline reflects unmeasured losses in favor of the view that it reflects the erosion of future profits, for the reasons suggested in the previous paragraph. They do not estimate how much of the decline is due to regulatory changes and how much is due to changed economic conditions, but they suggest that both are important factors. ${ }^{41}$

A more recent research note by the Clearing House attributes the vast majority of the decrease in market-to-book ratios to changes in the regulatory environment. Specifically, "for the largest banks-those above $\$ 250$ billion in total assets- the most important driver of the decline in ROTCE [return on tangible common equity] is the reduction in fee income" (Clearing House 2016, p. 6). They also find that "perhaps surprisingly, net interest margins have narrowed only modestly across all bank groups,"

41. Part of this decline is likely attributable to reduced value of retail deposits. The median core deposit premium fell from around 15.5 percent in 2004 to around 3.3 percent in 2013 (Mecredy 2014). As an example, consider the impact of this decrease for Bank of America, whose deposits are 55 percent of total assets. Assuming this proportion has been stable over time, franchise value from bank deposits has fallen from 8.25 percent of total assets ( $\$ 1.1$ trillion) in 2004 to 1.65 percent (of $\$ 2.11$ trillion) in 2013, which translates to a decrease of around $\$ 55$ billion. 
which they argue is evidence that "the low level of interest rates and the relatively flat yield curve have had less adverse impact on bank profitability than commonly assumed" (Clearing House 2016, p. 4).

Canada is often highlighted as a G-7 country that came through the financial crisis without great damage to its financial system or the need for large-scale public interventions. It is noteworthy that its banks have been consistently able to maintain a price-to-book ratio that is high by international standards. A similar observation holds for Australia, which is also thought to have come through the financial crisis well. This tends to support the idea that franchise value in a financial system is stabilizing and to confirm the idea that substantial losses in franchise value can be destabilizing.

It is worth noting that while franchise value probably explains the decline in price-to-book ratios in the United States, the observation that price-to-book ratios are well below 1 for many European institutions suggests the relevance of asset misvaluation. Acharya, Pierret, and Steffen (2016) conclude that the extremely low average price-to-book ratio of 0.7 is reflective of market participants discounting bank asset values heavily. The fact that this ratio (which averaged above 1 in 2014) has declined so precipitously in the last few years reflects "increasing concerns of market participants on bank asset quality compared to the valuation of bank assets in their balance sheets" (Acharya, Pierret, and Steffen 2016, p. 6). These authors suggest that the low price-to-book ratios in Europe reflect the market's belief that banks will become undercapitalized more rapidly in a stress scenario than the conventional stress test results reveal. They argue for "a comprehensive recapitalization" across almost all European countries, which is consistent with Vickers' (2016) call for increased equity capital for U.K. banks and Admati and Hellwig's (2013) view.

\section{Conclusions}

As Haldane and Vasileios Madouros (2012) point out, market measures of risk are invaluable in assessing banks' ability to withstand adverse shocks. They note that in a horse race between the simplest market measure of risk (the market value of equity relative to unweighted assets) and the most complex regulatory measure (the Basel III Tier 1 ratio), the explanatory power of the simple measure in predicting bank failure is about 10 times greater than the complex one. As such, we feel our focus on market measures of bank risk is a sensible one. 
We find that these measures are in the same range that they were prior to the financial crisis. This suggests cause for concern that there is a nontrivial probability of a major loss in equity value by a large financial institution sometime in the next few years. ${ }^{42}$ In fact, the ratio of market value of equity to assets preferred by Haldane and Madouros (2012) has actually decreased since the precrisis period. There is little if any evidence in the data on bank stock prices, options prices, bond prices, or preferred stock prices of the kinds of declines in risk that might be expected from the dramatic regulatory actions taken to increase capital and reduce risk-taking.

Regulators like Mark Carney and Janet Yellen have repeatedly made clear that they believe that banks are much safer today than they were before the crisis. To provide support for this claim, they point to Tier 1 capital ratios, which have more than doubled since 2009 (Carney 2016a). We hope our paper encourages greater skepticism about the relationship between bank safety and these measures. The gains that regulators celebrate are attributable to increases in tangible capital as a consequence of DoddFrank and related regulation. And we firmly believe that the financial system would be more fragile but for these regulatory reforms. However, while increasing tangible capital, these changes-and the macroeconomic environment more broadly - have also impinged on bank franchise value. And thus, it is no surprise that market measures of risk reflect so few gains relative to the precrisis period.

It is important to emphasize also that our analysis focuses on bank solvency. Substantial risks in the banking system come not from insolvency but from illiquidity - from the risks of runs on even solvent institutions and of contagion once concerns about viability become apparent. While it is not the focus of our study, we find it highly plausible that a combination of regulatory action and prudent private sector behavior has substantially reduced run risks.

Indeed, while much of the traditional discussion of financial stability focuses on the possibility that a solvent institution will become illiquid and experience a run, our analysis leads us to focus on the possibility that an institution can be liquid but insolvent. Consider a bank whose assets, properly valued, are worth less than its liabilities, but that funds substantially with either insured deposits or has substantial outstanding long-term debt. It is easy to imagine that if it has access to the discount window and can borrow against its assets, this bank's unsecured short-term creditors need

42. Of course, we are witnessing such a decline already in the case of Deutsche Bank. 
have no concerns about their liabilities. Such an institution does not pose near-term systemic risk. There is, for example, no reason for other banks to refuse to extend credit or do business with it. However, its insolvency may well badly distort the incentives of its managers and lead to deposit insurance liabilities.

We believe that there is little basis for supposing that the risks of major institutions becoming insolvent are substantially lower than they were before the crisis. Measured at market value, equity buffers are smaller than they were even in the early part of the last decade. And volatility and beta measures suggest that the risk of equity values falling to zero has not been attenuated.

Our emphasis on market values also raises questions about stress-testing methodologies. U.S. regulators carry out stress tests using very draconian scenarios. As Bulow and Klemperer (2013) note, one year's stress test involved a stock market decline of nearly 60 percent and an increase in unemployment to 13 percent. All the major banks passed the test with relatively little estimated diminution in capital.

Yet, we believe that in such a scenario, it is a near certainty that absent government support or new capital-raising, at least some bank equities would fall to zero. Applying the average postcrisis beta for the Big 6 banks of 1.59 , just over a 60 percent decline in the market would wipe out these banks' equity. This calculation substantially underestimates the risk because it ignores the increase in equity beta that would result as banks lost equity value and so became more levered, and it also ignores the fact that as the economy turns down, bank assets become volatile as loan values become dependent on collateral values.

What does all this imply for financial regulatory policy? The fact that the ratio of market value of equity to total assets is so low by historical standards is not a place where the regulatory community should be content to rest comfortably. One credible policy response to which we are sympathetic is Bulow and Klemperer's (2015) view that the greatest unmet challenge of financial regulation is ensuring that institutions raise equity capital when necessary. This would protect debt holders, deposit insurers, and taxpayers more generally. In that sense, while perhaps equity holders would be concerned about becoming diluted, we would not worry about the possibility of a bank run, contagion, or costly government intervention in moments of crisis.

We are skeptical that such a commitment to dilutive equity issues is in place. For all the many changes that have been made in regulation and supervision, there has been little movement toward using market signals 
in gauging risk. While we certainly do not believe that robust market values and low credit spreads are any basis for complacency, we do believe that sharply deteriorating market conditions are grounds for alarm. We suspect that the same desire to maintain confidence that prevented actions from being taken to force capital-raising or even cut dividends in 2008 is likely operative today.

Deutsche Bank is a cautionary example of overreliance on regulatory measures of capital. In February 2016, as the share price dropped by nearly 10 percent in a single day (evincing markets' belief that the firm was in trouble), Deutsche Bank CEO John Cryan assured the bank's employees that it was "absolutely rock-solid," citing as evidence its "strong capital and risk position" (Cryan 2016). Indeed, as late as October of 2016, when its price-to-book ratio was around 0.25 , the market value of its equity was equal to only 1 percent of its assets, and it was facing the possibility of a U.S. fine that could exceed half the value of its equity, Cryan was assuring investors that there were no plans to raise capital (Kirchfield, David, and Nair 2016).

Further corroboration of the idea that market participants do not expect prompt capital-raising in the face of adverse events comes from the relatively high yields (in excess of 5 percent) on new preferred stock issuances by leading U.S. banks discussed above. If there was confidence that capital sufficient to prevent insolvency would be raised in times of distress, this risk premium would be lower.

More rapid capital-raising in response to adversity could be achieved in a number of ways. It is, to be fair, the objective of stress-testing (though we are skeptical of such exercises) that they are carried out entirely with accounting measures of capital. An increase in capital in times of distress could also be achieved through triggers for regulatory action tied to equity values or measures of credit spreads. There is also a possible role for instruments that have mandatory conversion features based on movements in securities prices, such as the Equity Recourse Notes proposed by Bulow and Klemperer (2013, 2015).

An alternative strategy is to simply buttress capital levels and hope that they are sufficient to deal with adverse scenarios, even if regulatory responses are sluggish. We are somewhat wary of this approach. The observation that most failures involve situations where the capital hole is 15 percent or more of capital — and in some cases like IndyMac exceeds 40 percent of capital—suggests that the required increases in capital ratios under this approach are likely to be very large. If such increases were imposed, the likely result would be the large-scale transfer of activity 
from the regulated system to the shadow banking system, which could have the effect of reducing safety and soundness.

We believe that regulations in areas like overdraft fees should be decided on their merits rather than on the basis of a desire to make banking more profitable, so direct public policy to increase franchise value also seems to us very much a second-best approach to promoting stability.

In future research, it would be valuable to develop a better understanding of the reasons for fluctuations in the ratio of banks' equity value to assets-a measure we identify as a crucial indicator of safety. It would also be useful to consider approaches to regulation that can overcome the fear of undermining confidence consideration that inhibits capital-raising during downturns. And careful consideration of the roles of insolvency and illiquidity in financial crises is important, with our suspicion being that the focus may have shifted excessively toward issues of illiquidity.

None of this suggests to us that the broad approach taken by the regulatory community in the wake of the 2008 financial crisis of increasing capital and seeking to contain risk-taking was inappropriate. We believe however that our results make a strong case for concern about the current stability of the financial sector, for greater attention to market valuations in assessing financial institutions' health, and for prompter responses to adverse events than were forthcoming in the United States in 2008 and appear to be forthcoming in Europe today.

ACKNOWLEDGMENTS We are grateful to Michael Barr, Mark Carney, Janice Eberly, Andrew Haldane, Thomas Philippon, Peter Sands, Jeremy Stein, James Stock, Paul Tucker, John Vickers, Matthew Zames, and participants in the Fall 2016 Brookings Papers on Economic Activity conference for helpful comments on drafts of this paper. We also thank Andrew Sacher and the Harvard Business School Baker Library staff for data assistance. Conversations with Jeremy Bulow both before the paper was written and on its drafts were invaluable. This paper was written before the U.S. presidential election on November 8, 2016, and does not consider its impact. Data used in this paper are to year-end 2015, unless noted otherwise. 


\section{References}

Acharya, Viral V., Lasse H. Pedersen, Thomas Philippon, and Matthew Richardson. 2017. "Measuring Systemic Risk." Review of Financial Studies 30, no. 1: 2-47.

Acharya, Viral V., Diane Pierret, and Sascha Steffen. 2016. "Capital Shortfalls of European Banks since the Start of the Banking Union." Working paper. http://pages.stern.nyu.edu/ sternfin/vacharya/public_html/pdfs/shortfalls_v27 July2016\%20(1).pdf

Acharya, Viral V., and Sascha Steffen. 2014. "Falling Short of Expectations? Stress-Testing the European Banking System.” Policy Brief no. 315. Brussels: Centre for European Policy Studies.

Acharya, Viral, Hyun Song Shin, and Irvind Gujral. 2009. "Bank Dividends in the Crisis: A Failure of Governance." Online article. London: Centre for Economic Policy Research, VoxEU.

Admati, Anat, and Martin Hellwig. 2013. The Bankers' New Clothes: What's Wrong with Banking and What to Do about It. Princeton University Press.

Baker, Dean. 2015. "More on TBTF: Quick Rejoinder to Mike Konczal.” Beat the Press blog, October 17. Washington: Center for Economic and Policy Research.

Baker, Malcolm, and Jeffrey Wurgler. 2015. "Do Strict Capital Requirements Raise the Cost of Capital? Bank Regulation, Capital Structure, and the Low-Risk Anomaly." American Economic Review 105, no. 5: 315-20.

Barro, Robert J., and Gordon Y. Liao. 2016. "Options-Pricing Formula with Disaster Risk." Working Paper no. 21888. Cambridge, Mass.: National Bureau of Economic Research.

Bulow, Jeremy, and Paul Klemperer. 2013. "Market-Based Bank Capital Regulation.” Research Paper no. 2132. Stanford: Stanford University, Rock Center for Corporate Governance.

_. 2015. "Equity Recourse Notes: Creating Counter-Cyclical Bank Capital." Economic Journal 125, no. 586: F131-F157.

Calomiris, Charles W., and Doron Nissim. 2014. "Crisis-Related Shifts in the Market Valuation of Banking Activities." Journal of Financial Intermediation 23, no. 3: 400-35.

Cao, Charles, Fan Yu, and Zhaodong Zhong. 2010. "The Information Content of Option-Implied Volatility for Credit Default Swap Valuation.” Journal of Financial Markets 13, no. 3: 321-43.

Carney, Mark. 2014. "The Future of Financial Reform.” Speech given at the Monetary Authority of Singapore Lecture, Monetary Authority of Singapore, Singapore, November 17.

__ 2016a. "Redeeming an Unforgiving World." Speech given at the 8th Annual IIF G20 Conference: The G20 Agenda Under the Chinese Presidency, Institute for International Finance, Shanghai, February 26.

. 2016b. "Statement Following the EU Referendum Result." News Release, June 24. Bank of England. 
Caruana, Jaime. 2012. "Building a Resilient Financial System." Speech given at the ADB Financial Sector Forum on Enhancing Financial Stability-Issues and Challenges, Asian Development Bank, Mandaluyong, Philippines, February 7.

Christensen, Bent J., and Nagpurnanand R. Prabhala. 1998. "The Relation between Implied and Realized Volatility." Journal of Financial Economics 50, no. 2: $125-50$.

Clearing House. 2016. "Why Have Banks' Market-to-Book Ratios Declined?" Research Note, November 1. New York. https://www.theclearinghouse.org/ issues/articles/2016/11/20161101_tch_research_note_market-to_book_ratios

Collin-Dufresne, Pierre, Robert S. Goldstein, and J. Spencer Martin. 2001. "The Determinants of Credit Spread Changes." Journal of Finance 56, no. 6: 2177-207.

Cox, Christopher. 2008. "Testimony Concerning the Role of Federal Regulators: Lessons from the Credit Crisis for the Future of Regulation." Testimony before the Committee on Oversight and Government Reform, U.S. House of Representatives, October 23. https://www.sec.gov/news/testimony/2008/ ts $102308 \mathrm{cc} . h \mathrm{tm}$

Cryan, John. 2016. "A Message from John Cryan to Deutsche Bank Employees." February 9. Frankfurt: Deutsche Bank.

Dash, Eric. 2009. "U.S. Agrees to Raise Its Stake in Citigroup." New York Times, February 27.

Elsby, Michael W. L., Bart Hobijn, and Ayşegül Şahin. 2010. "The Labor Market in the Great Recession." Brookings Papers on Economic Activity, Spring: 1-48.

Erkens, David H., Mingyi Hung, and Pedro Matos. 2012. "Corporate Governance in the 2007-2008 Financial Crisis: Evidence from Financial Institutions Worldwide." Journal of Corporate Finance 18, no. 2: 389-411.

Fahlenbrach, Rüdiger, Robert Prilmeier, and René M. Stulz. 2012. "This Time Is the Same: Using Bank Performance in 1998 to Explain Bank Performance during the Recent Financial Crisis." Journal of Finance 67, no. 6: 2139-85.

Gehrig, Thomas. 2016. "Price Discovery during Anomalous Market Trading: The Lehman Brothers Case." Online article. London: Centre for Economic Policy Research, VoxEU.

Gunn, Murray. 2009. Trading Regime Analysis: The Probability of Volatility. Hoboken, N.J.: Wiley.

Haldane, Andrew. 2014. "Constraining Discretion in Bank Regulation." In Central Banking at a Crossroads: Europe and Beyond, edited by Charles Goodhart, Daniela Gabor, Jakob Vestergaard, and Ismail Ertürk. London: Anthem Press.

Haldane, Andrew, and Vasileios Madouros. 2012. "The Dog and the Frisbee." In Economic Policy Symposium Proceedings: The Changing Policy Landscape. Jackson Hole, Wyo.: Federal Reserve Bank of Kansas City.

IMF (International Monetary Fund). 2016. Global Financial Stability Report: Fostering Stability in a Low-Growth, Low-Rate Era, October. Washington.

Johnson, Simon, and James Kwak. 2010. "Capital Requirements Are Not Enough." Economix blog. New York Times, April 1. 
Katz, Lawrence F. 2010. "Long-Term Unemployment in the Great Recession." Testimony before the Joint Economic Committee, U.S. Congress, April 29. http://scholar.harvard.edu/lkatz/publications/long-term-unemployment-greatrecession

Khan, Urooj, Oded Rozenbaum, Gil Sadka. 2013. "Bias and Efficiency: A Comparison of Analyst Forecasts and Management Forecasts." Working paper. https:// papers.ssrn.com/sol3/papers.cfm?abstract_id=2177992

Kirchfeld, Aaron, Ruth David, and Dinesh Nair. 2016. "Deutsche Bank Said to Weigh Capital Options with Lenders.” Bloomberg Markets, October 6.

Konczal, Mike. 2015a. "Four Ways of Looking at a TBTF Subsidy: A Reply to Dean Baker." Roosevelt Forward blog, October 17.

—. 2015b. "Two Opposing Methods Tell Us the Too Big to Fail Subsidy Has Collapsed." Roosevelt Forward blog, June 11.

—. 2016. "Larry Summers Makes the Case for Higher Capital Requirements." Roosevelt Forward blog, September 20.

Liu, Berlinda. 2012. "Volatility Benchmarks in Europe.” VIX Views, January 7. New York: S\&P Dow Jones Indices.

Lo, Andrew W., and A. Craig MacKinlay. 1989. "The Size and Power of the Variance Ratio Test in Finite Samples: A Monte Carlo Investigation." Journal of Econometrics 40, no. 2: 203-38.

Mecredy, Thomas R. 2014. "Merger \& Acquisition, Community Bank Valuation \& Capital Markets Update." Presentation at ICBA Community Bank Day, Independent Community Bankers of America, May 20. https://www.scribd.com/ presentation/333569917/Mergers-Acquisitions-Capital-Markets-Bank-ValuationUpdate

Obama, Barack. 2013. "Remarks by the President at the Five-Year Anniversary of the Financial Crisis." September 16. Washington: White House.

Pacati, Claudio. 2013. "Calculations of Greeks in the Black and Scholes Formula." https://www.scribd.com/document/333640395/Calculations-of-Greeks-in-theBlack-and-Scholes-Formula

Poterba, James M., and Lawrence H. Summers. 1988. "Mean Reversion in Stock Prices: Evidence and Implications." Journal of Financial Economics 22, no. 1: 27-59.

Rajan, Raghuram G. 2005. "Has Financial Development Made the World Riskier?" In Economic Policy Symposium Proceedings: The Greenspan Era-Lessons for the Future. Jackson Hole, Wyo.: Federal Reserve Bank of Kansas City.

Schwert, G. William. 1989. "Why Does Stock Market Volatility Change Over Time?" Journal of Finance 44, no. 5: 1115-53.

Sinclair, Euan. 2010. Option Trading: Pricing and Volatility Strategies and Techniques. Hoboken, N.J.: Wiley.

Thomson Reuters. 2008. "Datastream: Options User Companion, February 2008." http://docplayer.net/3495040-Datastream-options-user-companion.html 
Vickers, John. 2016. "The Systemic Risk Buffer for UK Banks: A Response to the Bank of England's Consultation Paper." Journal of Financial Regulation 2, no. 2: 264-82.

Yellen, Janet L. 2014. "Federal Reserve's Second Monetary Policy Report for 2014." Hearing before the Committee on Banking, Housing, and Urban Affairs, U.S. Senate, July 15. Senate Hearing no. 113-473, vol. 1. Washington: U.S. Government Publishing Office.

2015. "Finance and Society." Speech given at the Finance and Society conference, Institute for New Economic Thinking, Washington, May 6.

2016. "Semiannual Testimony on the Federal Reserve's Supervision and Regulation of the Financial System." Testimony before the Committee on Financial Services, U.S. House of Representatives, September 28. http://financial services.house.gov/calendar/eventsingle.aspx?EventID=401061 (1:35:04-1:35:43 and 3:08:17-3:08:49) 


\section{Comments and Discussion}

\section{COMMENT BY}

JEREMY BULOW The most recent Federal Reserve stress tests estimate what will happen to bank regulatory capital if GDP drops 6.25 percent, unemployment doubles, the stock market halves, and real estate falls by 25 to 30 percent. It estimates average capital losses of about 4 percent of assets, almost exactly half what it would take before triggering what is called "prompt corrective action." Is this a comment on the banks, or on the stress tests?

Natasha Sarin and Larry Summers apply a series of market tests. The authors show-in their measures of bank stock volatility, beta, priceearnings ratio, and out-of-the-money put option pricing-that the market's risk-neutral probability that the major banks will lose their equity is about as high as, if not higher than, it was in 2007.

For a variety of reasons, stock price volatility might not directly correlate with default probability, so Sarin and Summers next look at credit default swap spreads, which take into account the chance that a bank will raise additional money and sell some of its risks on the way down, and the probability that there will be a bailout. Implied default probabilities are up, and are highest for the less-likely-to-be-bailed-out investment banks. Finally, they look at preferred stock, which should incorporate the probability that a bank will raise new funds and sell risks as it loses capital, but which has a lower probability of bailout. If anything, market risks are higher now.

1. The stress test banks would decline from 12.3 to 8.4 percent common equity Tier 1 capital, from 13.5 to 9.8 percent total Tier 1 , and from 16.2 to 12.3 percent total capital. These ratios would have to fall to 4.5 percent, 6 percent, and 8 percent, respectively, for a bank to no longer be rated as adequately capitalized. See Federal Reserve Board (2016, table 2, p. 23) and FDIC (2016, section 2.1, p. 8). 
Table 1. Risk Capital as a Percent of Assets, 2007 and 2015

\begin{tabular}{|c|c|c|c|}
\hline \multirow[b]{2}{*}{ Bank } & \multicolumn{2}{|c|}{$\begin{array}{l}\text { Risk capital (tangible equity) } \\
\text { as a percent of assets }{ }^{\mathrm{a}}\end{array}$} & \multirow{2}{*}{$\begin{array}{l}\begin{array}{l}\text { Risk-weighted assets as a } \\
\text { percent of tangible assets }\end{array} \\
2015\end{array}$} \\
\hline & 2007 & 2015 & \\
\hline Bank of America & $15.8(3.6)$ & $20.3(8.8)$ & 77 \\
\hline Citigroup & $22.5(2.3)$ & $23.4(11.6)$ & 71 \\
\hline Goldman Sachs & $18.1(3.4)$ & $30.1(9.6)$ & 67 \\
\hline JPMorgan Chase & $16.9(4.8)$ & $21.2(8.6)$ & 65 \\
\hline Morgan Stanley & $21.6(2.7)$ & 28.3 (8.6) & 49 \\
\hline Wells Fargo & $23.7(5.9)$ & $20.7(9.4)$ & 72 \\
\hline Commercial banks & $19.3(3.7)$ & $21.3(9.5)$ & 71 \\
\hline Investment banks ${ }^{\mathrm{c}}$ & $19.8(3.1)$ & $29.3(9.1)$ & 58 \\
\hline
\end{tabular}

Source: Author's calculations.

a. Risk capital is long-term debt plus tangible equity, which is defined as equity minus goodwill and intangibles other than mortgage servicing rights. The values in parentheses are tangible equity as a percent of assets.

b. The four commercial banks are Bank of America, Citigroup, JPMorgan Chase, and Wells Fargo.

c. The two investment banks are Goldman Sachs and Morgan Stanley.

The authors' lead explanation is the sharp decline in the value of banks' intangible assets since the crisis, as some businesses have become less profitable and some profitable businesses have been sold, sometimes to build regulatory capital. Goldman Sachs traded at about three times tangible equity per share before the crisis. Since then, its tangible equity has doubled, but its share price and assets per share have declined by about a third, leaving the company with a much improved regulatory capital leverage ratio, but only a slightly improved market ratio. ${ }^{2}$ So what have the regulators done right, and what needs to be done to make the banks actually safer?

In a nonfinancial firm, both equity and long-term unsecured debt can serve as risk capital. But during the crisis, it was almost impossible to impose losses on long-term bank debt. So regulators have encouraged commercial banks to shift from long-term debt to equity, though the total of the two as a percent of assets has not risen much, as shown in my table 1. Furthermore, efforts are being made to make long-term debt-particularly at the level of bank holding companies- "cleaner," so that a failure of the parent company will be less consequential for the operations of its bank subsidiary. While the improvements so far may have been offset by the decline in intangibles, they are improvements nonetheless.

But we are failing in at least four other important respects.

2. In the month after the U.S. presidential election, Goldman Sachs's stock rose to about 1.4 times tangible equity. 
Table 2. Marks of Commercial Banks versus Investment Banks

\begin{tabular}{lccc} 
Bank & $\begin{array}{c}\text { Commercial } \\
\text { real estate }\end{array}$ & $\begin{array}{c}\text { Subprime } \\
\text { collateralized } \\
\text { debt obligations }\end{array}$ & $\begin{array}{c}\text { Alternative } \\
\text { A-paper loans }\end{array}$ \\
\hline $\begin{array}{l}\text { Commercial banks } \\
\text { Bank of America }\end{array}$ & 96 & 44 & \\
Citigroup & 95 & 46 & 80 \\
Wachovia & 91 & 58 & 55 \\
Investment banks & & & 39 \\
Lehman Brothers & 85 & 29 & 35 \\
Merrill Lynch & 75 & $22^{\text {a }}$ & \\
Morgan Stanley & & 15 & \\
\hline
\end{tabular}

Source: Goldman Sachs (2008); for examples with identical assets, see AIG (2008).

a. Merrill Lynch's collateralized debt obligations had been marked at 36 before a sale.

First, total levels of capital required are still probably too low. The large commercial banks are at 20 to 23 percent equity plus long-term debt, versus 28 to 30 percent for the investment banks, which must borrow in markets rather than with deposit guarantees - and this even though the investment banks hold assets with lower average risk weights and greater liquidity. A way to think of this is that even if long-term debt counts as risk capital, the haircuts applied by the regulatory system to commercial banks are almost surely below market.

Second, there has been no move to mark bank assets to market or fair value, or to use markets to determine appropriate haircuts. As we can see from my table 2, even for assets that they were supposed to mark to market, the commercial banks mismarked relative to the much more conservative investment banks such as Lehman Brothers. ${ }^{3}$ This mismarking, as well as the retention of high-risk assets, is encouraged by the regulatory capital system. The sale of a subprime mortgage worth 20 but marked at 50 with a 10 percent capital requirement reduces risk but requires the bank to raise an additional 25 in cash. The mismarking also discourages the raising of new risk capital. For example, if regulatory capital is 10 per share while the stock price is 2 , a bank must increase its share count by 5 percent if it wishes to expand its asset base by 1 percent and retain the same regulatory debt-equity ratio. ${ }^{4}$ Finally, because the sclerotic regulatory capital system

3. See Goldman Sachs $(2008,2009)$ and AIG (2008). The other investment banks appear to have been more conservative than Lehman Brothers.

4. So the net effect would be a reduction in market leverage, unwelcome to banks because it would transfer wealth to deposit insurers and possibly other creditors. See Acharya and others (2012) for a comprehensive study of the capital-raising of major banks during the crisis. 
realizes losses so slowly, it effectively places short-term unsecured bank debt ahead of the bank insurer, because there will be time to run between when the bank becomes insolvent and when it runs out of regulatory capital.

The importance of adequately marking assets can be thought of this way: While some complained that investment banks were underregulated relative to the commercial banks, it is hard to think of what would be more important for bank safety than to make sure the bank assets were worth what they claimed. We are continuing this mistake by employing stress tests that explicitly ignore market information. ${ }^{5}$

Third, despite all the effort so far, are we really confident that the regulators will allow another failure, even at a major investment bank? The vast complexity of Basel III-which is far beyond that of the humanly incomprehensible Basel II-makes one doubt. ${ }^{6}$ We need to make long-term debt and other forms of unsecured obligations, including lines of credit and unsecured claims against derivatives contracts, explicitly incapable of triggering a default. This makes much more sense than the government agreeing to be effectively the bank's junior creditor in return for an insurance premium of 10 basis points.

Fourth, we need a system where as asset values fall, balance sheets selfrepair, and banks are automatically incentivized to add risk capital in bad times, as Paul Klemperer and I (2015) suggest. Without such a system, we are still seeing events in 2016 like the Deutsche Bank crisis referred to by Sarin and Summers, and the Italian banking crisis featuring Banca Monte dei Paschi di Siena. Even if there is no taxpayer loss in resolving a bank's current debts, there is risk if on the way down the banking system needs more capital and banks will not raise it voluntarily.

Sarin and Summers show, in a way that is much more convincing than has been done before, that despite all the efforts of regulators and the decline in reported leverage ratios, there remain significant risks of failure in the banking system. Their data call into question whether the current

5. The important thing is not so much using markets to set values of assets as to determine the amount that can be borrowed against an asset. King (2016) suggests using measures akin to what the Bank of England uses when it lends against collateral. Bulow and Klemperer $(2013,2015)$ and Bulow, Goldfield, and Klemperer (2013) have suggested using the collateral requirements of private lenders. If the market will lend 70 against your Spanish government bond, then the capital requirement is $p-70$ where $p$ is your book value, regardless of whether you mark your bond at 75 or 95 . (Care must be taken in using market haircuts for systemically important financial institutions to make sure that the lender does not have an implicitly government-guaranteed claim for any shortfall in the value of the collateral.)

6. Basel I standards were 30 pages long; Basel II, 347 pages; and Basel III, 616 pages. In the United States, the Dodd-Frank Act is 2,300 pages long, with over 22,000 pages of regulations already issued. The calculation of regulatory capital requirements typically requires several thousand parameters. See, for example, Haldane and Madouros (2012). 
system will really require banks to raise adequate new capital when they incur losses. They look for the evidence that moving from an impossibly complicated system to a much more complicated one is helping, but cannot find it. While markets are too pessimistic about half the time, Sarin and Summers ask whether we can be satisfied with letting taxpayers bear the risk that maybe market prices are right or even optimistic. This is an enormously valuable paper that not only calls into question the safety of the banking system, but also asks whether the approach that has been followed for the last seven years is really the right one.

\section{REFERENCES FOR THE BULOW COMMENT}

Acharya, Viral V., Irvind Gujral, Nirupama Kulkarni, and Hyun Song Shin. 2012. "Dividends and Bank Capital in the Financial Crisis of 2007-2009." Working paper. http://pages.stern.nyu.edu/ sternfin/vacharya/public_html/BankCapital AcharyaGujralKulkarniShin_JACF.pdf

AIG (American International Group). 2008. "Collateral Call Status." https://www. scribd.com/document/334295661/1031-AIG-Collateral-Marks

Bulow, Jeremy, Jacob Goldfield, and Paul Klemperer. 2013. "Market-Based Bank Capital Regulation." Online article. London: Centre for Economic Policy Research, VoxEU.

Bulow, Jeremy, and Paul Klemperer. 2013. "Market-Based Bank Capital Regulation." Research Paper no. 2132. Stanford: Stanford University, Rock Center for Corporate Governance.

—. 2015. "Equity Recourse Notes: Creating Counter-Cyclical Bank Capital." Economic Journal 125, no. 586: F131-F157.

FDIC (Federal Deposit Insurance Corporation). 2016. "Risk Management Manual of Examination Policies." Washington. https://www.fdic.gov/regulations/safety/ manual

Federal Reserve Board. 2016. "Dodd-Frank Stress Test 2016: Supervisory Stress Test Methodology and Results." Washington. https://www.federalreserve.gov/ newsevents/press/bcreg/bcreg20160623a1.pdf

Goldman Sachs. 2008. "Company Update: Morgan Stanley \& Co. (MS) Reiterate Our Conviction Buy on Exaggerated Market Fears." September 19. Available upon request from Jeremy Bulow.

—_ 2009. "Valuation and Pricing Related to Transactions with AIG." Production no. GS MBS 0000039096. New York. http://www.goldmansachs. $\mathrm{com} / \mathrm{media}-\mathrm{relations} /$ in-the-news/archive/response-to-fcic-folder/valuationand-pricing.pdf

Haldane, Andrew, and Vasileios Madouros. 2012. "The Dog and the Frisbee." In Economic Policy Symposium Proceedings: The Changing Policy Landscape. Jackson Hole, Wyo.: Federal Reserve Bank of Kansas City.

King, Mervyn. 2016. The End of Alchemy: Money, Banking, and the Future of the Global Economy. New York: W.W. Norton. 


\section{COMMENT BY}

THOMAS PHILIPPON This important paper by Natasha Sarin and Larry Summers challenges the received wisdom about banking regulation in the postcrisis era. Since 2009, banking regulation has evolved significantly: Regulators require more equity for banks in general; and systemically important financial institutions, in particular, are subject to multiple metrics (leverage, liquidity, Tier 1 capital) and methodologies (stress tests). In addition, regulators have improved cross-border planning and cooperation regarding global banks (Ingves 2015). As a result of these efforts, most analysts believe that banks today are significantly safer than they were before the global crisis.

THE PUZZLE The puzzle identified by Sarin and Summers is that marketbased measures of risk have not declined. The authors convincingly document this fact using an exhaustive array of market variables, including equity volatility, options prices, credit default swap (CDS) spreads, and preferred stock yields. As an additional piece of evidence, my figure 1 displays the measure of systemic risk developed by New York University's Volatility Laboratory (V-Lab), based on the work of Viral Acharya and others (2017) and Christian Brownlees and Robert Engle (2017). Systemic risk measures the potential shortfall of capital in a systemic crisis. It is conceptually similar to a stress test measure, but it is based on simulations of the market value of equity. V-Lab estimates systemic risk for each significant (and publicly traded) financial firm. My figure 1 shows the aggregate measure, for the entire U.S. banking system. At the peak of the crisis, U.S. systemic risk was close to $\$ 1$ trillion. Today it is less than $\$ 400$ billion. However, exactly as Sarin and Summers point out, it is significantly higher than during the precrisis period.

Regulations have increased the quantity and quality of bank capital relative to risk-weighted assets and total assets. How is it possible, then, that market-based measures of risk have not decreased? The answer is that, although the book value of equity has increased, the ratio of market value to book value has decreased, so that, on a market-value basis, it is unclear that banks have become less highly levered. The key evidence, from the authors' table 6 , is summarized in my table 1 , which shows a dramatic decline in the price-to-book ratio, and a decline in the ratio of the market value of equity to assets (MVE/A).

As a particularly striking example, my figure 2 shows the evolution of MVE/A for Citigroup. The first thing to notice is the sharp drop from 2000 to 2001, which shows that the valuation of banking stocks is subject to the same whims and caprices of market investors as nonfinancial stocks. If we 
Figure 1. U.S. Aggregate Systemic Risk, 2000-16

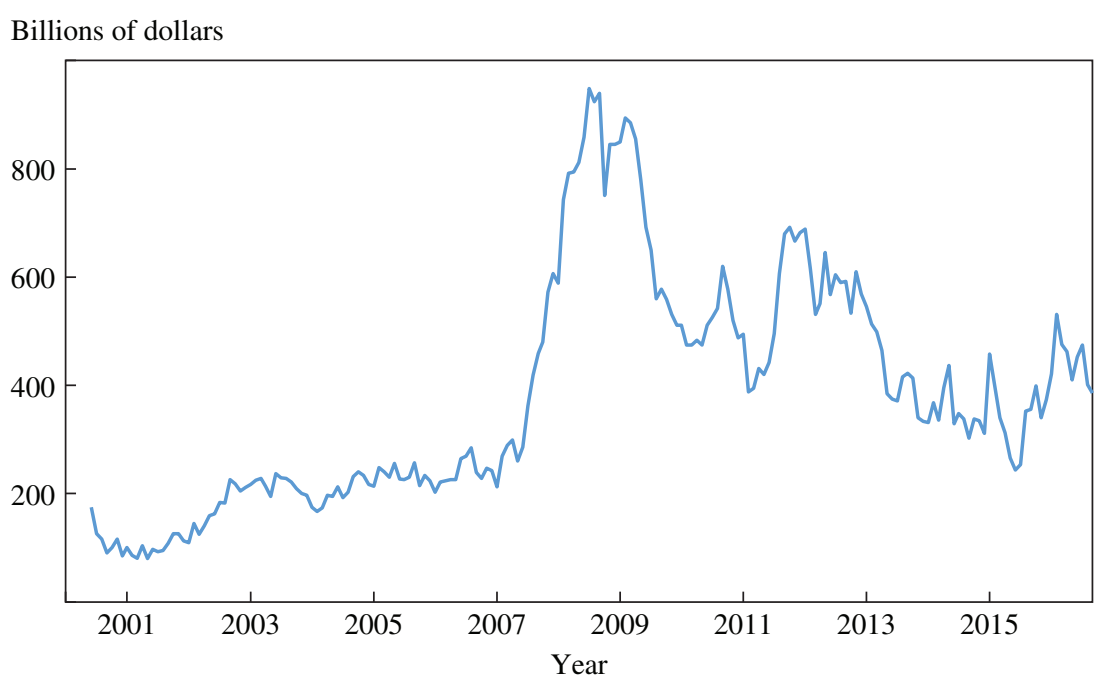

Source: V-Lab.

Table 1. Equity Ratios Precrisis and Postcrisis

Large U.S. banks

Price-to-book ratio

International banks

Price-to-book ratio

Source: Sarin and Summers.

look at the precrisis but post-2000 bubble, Citigroup had an MVE/A of about 0.15 . Today it is 50 percent lower, about 0.1 .

The challenge, then, is to explain the evolution of equity values, and to draw implications for financial regulations.

EXPLANATIONS AND POLICY IMPLICATIONS One explanation for the puzzle can be the repricing of systemic risk. Let $\pi$ be the probability of default. The valuation of bank equity is

$$
V_{t}=N I_{t}+\frac{(1-\pi) V_{t+1}+\pi V_{t+1}^{D}}{1+r},
$$


Figure 2. Ratio of Market Value of Equity to Assets for Citigroup, 2000-16

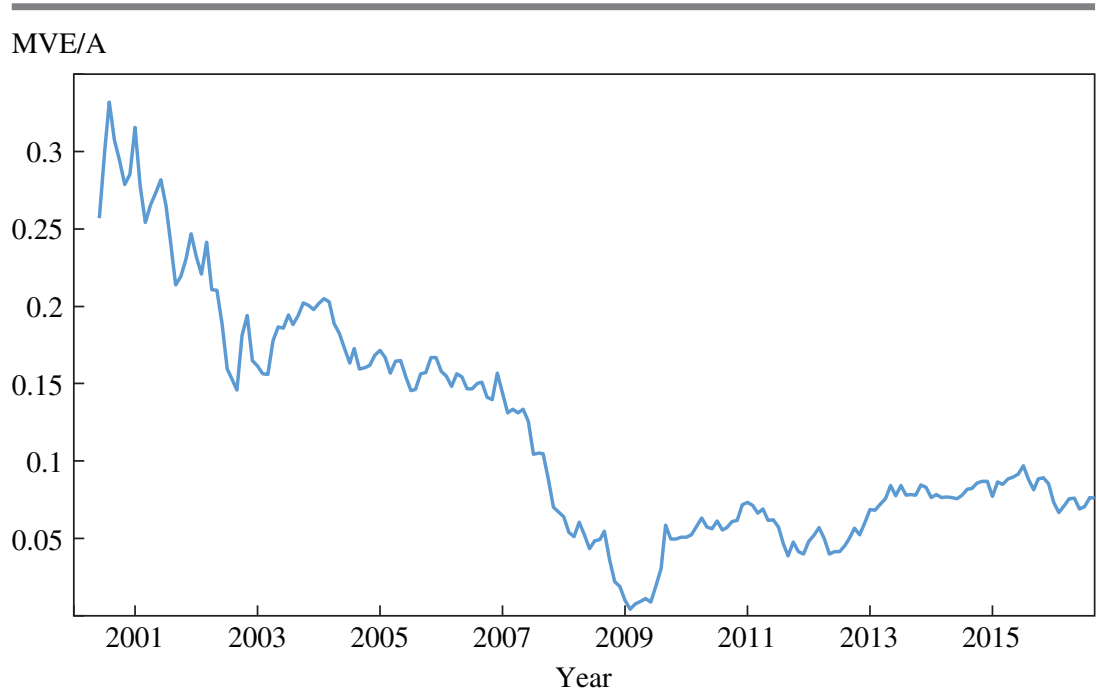

Source: V-Lab.

where $N I_{t}$ is net income, $V_{t+1}^{D}$ is the recovery value, and $r$ is the discount rate. We can scale this equation by assets $A_{t}$ and assume a constant return on assets (ROA); defining MVE/A as $v \equiv V_{t} / A_{t}$ and $d \equiv V_{t}^{D} / A_{t}$, we have

$$
v=R O A+\frac{(1-\pi) v+\pi d}{1+r}
$$

and finally,

$$
v=\frac{R O A+\frac{\pi d}{1+r}}{1-\frac{1-\pi}{1+r}} .
$$

My figure 3 shows that ROA was about 1.2 percent before the crisis and is now about 1 percent. At the same time, the risk of default, measured using CDS spreads, has increased from 32 to 94 basis points (see the authors' table 1). This can represent either a revision of investors' expectations regarding bank risk or a removal of too-big-to-fail subsidies.

We can use the equation above to do some back-of-the-envelope calculations. I set $d=0$ and I calibrate the discount rate $r$ so as to match the 
Figure 3. Return on Assets for U.S. Banks, 1984-2016

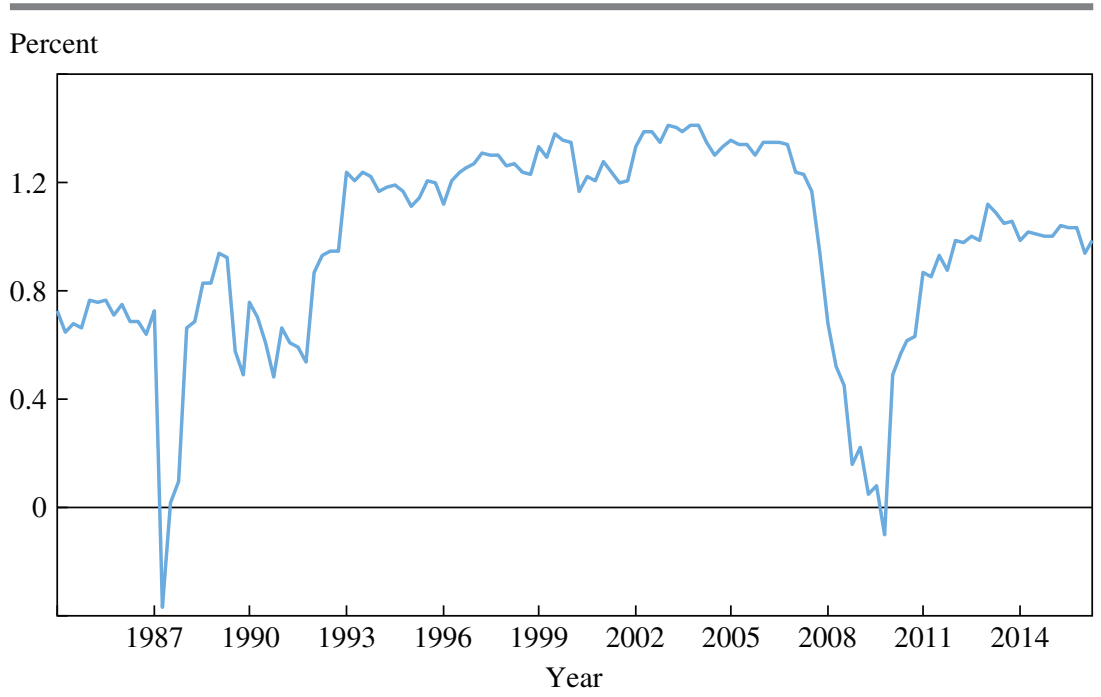

Source: Federal Reserve Economic Data.

Table 2. Actual and Predicted MVE/A $\mathrm{A}^{\mathrm{a}}$

\begin{tabular}{lllll}
\hline & Precrisis & & 2015 \\
\hline Actual MVE/A & 0.14 & & 0.10 & \\
$\pi$ & $0.32 \%$ & $0.94 \%$ & & $0.94 \%$ \\
ROA & $1.2 \%$ & $1.2 \%$ & & $1.0 \%$ \\
Predicted MVE/A & 0.14 & 0.13 & & 0.11 \\
\hline
\end{tabular}

Sources: Sarin and Summers; author's calculations.

a. The discount rate $r$ is calibrated to 9 percent to match MVE/A precrisis.

starting ratio of equity value to assets (this discount rate should take into account normal risk premiums, tax adjustments, and the like). My table 2 shows that the increase in default risk could account for a decrease in $v$, from 0.14 to 0.13 . Adding the change in ROA, $v$ drops further, to 0.11 , which is close to 0.10 in the data.

It seems, therefore, that the decline in the market value of equity can be accounted for by a decline in ROA or a repricing of risk. This is consistent with the idea that market participants underestimated the risk of a severe financial crisis before 2008. Sarin and Summers test for serial correlation in equity returns, but note that the idea that underestimation of $\pi$ precrisis would lead to serial correlation is only true if the news that drives returns is indeed about $\pi$. If the information is about something else (business as 
Figure 4. GDP Shares of Finance, 1963-2016

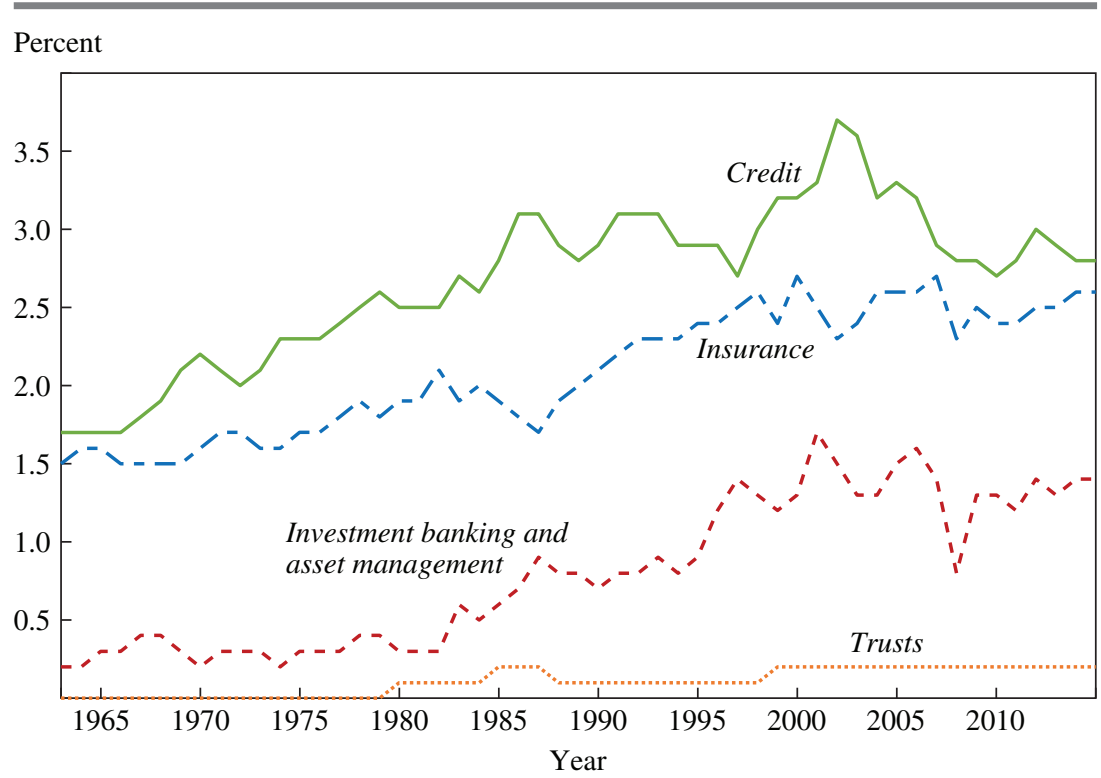

Source: U.S. Bureau of Economic Analysis.

usual), then we do not expect serial correlation. In other words, the serial correlation test cannot rule out a peso-problem explanation.

The decline in ROA has several possible explanations. Low interest rates decrease the franchise value of core deposits, while low credit demand from firms and households decreases the value of credit intermediation. Other explanations for the decline in ROA are more structural. It could be due to heavy-handed regulation, or to increasing competition by nonbank actors, financial technology firms in particular (Philippon 2016). Finance, as a whole, has shrunk only moderately since 2009 , but banking has receded more significantly, as shown in my figure 4.

Risk underpricing can also account for the higher ROA before the crisis. The valuation equation above assumes that investors share a common belief about $\pi$. If some investors underestimate credit risk in U.S. markets, then banks can take advantage of it by manufacturing risky bonds and selling them to naive investors. ${ }^{1}$ To the extent that these investors are not pricing

1. Apparently, Wall Street bond traders located many of the mythical buyers in the city of Düsseldorf. See Lewis (2011). 
CDSs at the margin, this is likely to appear as high ROA rather than low $\pi$, even though in both cases the driving force is an underestimation of risk.

More work is needed to draw clear policy implications. Two areas in particular need to be explored. First, we need to understand exactly how regulation affects the valuation of banks. On one hand, if the drop in the market value of equity only reflects the removal of (some) too-big-to-fail subsidies, then we need not be concerned. If, on the other hand, excessive regulations drive up the cost of business and lower ROA, we should be worried.

Finally, we need to recognize that the market value of bank equity might not be a sufficient statistic for systemic risk, although it is the natural starting point. To see why, consider a regulation, such as minimum liquidity coverage, that forces banks to hold liquid assets with low yields in order to improve recovery and resolution. Such a regulation would lower the market value of equity and yet lower systemic risk at the same time. In other words, the likelihood of equity reaching zero is important, but what happens after it reaches zero also matters a great deal.

\section{REFERENCES FOR THE PHILIPPON COMMENT}

Acharya, Viral V., Lasse H. Pedersen, Thomas Philippon, and Matthew Richardson. 2017. "Measuring Systemic Risk." Review of Financial Studies 30, no. 1: 2-47. Brownlees, Christian, and Robert F. Engle. 2017. "SRISK: A Conditional Capital Shortfall Measure of Systemic Risk." Review of Financial Studies 30, no. 1: 48-79.

Ingves, Stefan. 2015. "Speech by Stefan Ingves at the IIF Annual Membership Meeting." Institute for International Finance, Lima, October 9.

Lewis, Michael. 2011. Boomerang: Travels in the New Third World. New York: W. W. Norton.

Philippon, Thomas. 2016. "The FinTech Opportunity.” Working Paper no. 22476. Cambridge, Mass.: National Bureau of Economic Research.

GENERAL DISCUSSION Robert Hall began by stating that a simple principle of bank risk analysis-which, according to him, was very amply supported by the paper-is that a bank is close to insolvent if its stock price drops below its ATM fee. He observed that this is exactly what happened to Citibank in 2008 before the financial crisis, which was "utterly ignored by regulators who were dazzled by a substantial amount of regulatory capital." What the paper shows, according to Hall, is that banks are still highly prone to insolvency. But the paper stops there, and there is more to be done. In principle, much progress has been made in designing 
"fail soft" financial institutions. Whether these fail soft features are going to work is still up in the air, according to Hall, but insolvency should not cause a financial institution to shut down. It did in the case of Lehman Brothers-with tragic consequences_-but much progress has been made since then to keep it from happening.

Hall went on to note that modern banking laws provide for the 24-hour resolution of an insolvent bank, whereby all its operating units simply continue operating. If a bank is declared insolvent, a large quantity of its subordinated debt (as much as necessary) is converted into an equity claim. On the strength of this claim, the government can, with complete safety, recapitalize all the bank's operating units. But the problem with Lehman Brothers was that it had more than 2,000 operating units. According to Hall, with the new legal design, the principle of a single point of entry, and many other features-such as living wills (done properly) and much subordinated debt — equity is no longer necessary. He contended that there was no reason to focus on equity, and he was happy to see that the paper did not particularly do this.

Capital and equity are not as important as the need to reorganize, Hall stated. Instead, one should just assume that there are going to be many insolvencies, but insolvency is not going to be an issue for the global financial system. Three-quarters of all venture-backed companies cease operations because they are close to running out of cash, Hall noted, and it never causes any systemic problems, no matter how big they are. So the key question one should be asking is, building on this paper, whether policymakers have become smart enough to live with the fact that insolvent banks disappoint their subordinated debt holders, but that that should have no further consequences for the global financial system.

Donald Kohn remarked that the Bank of England's Financial Policy Committee had come to nearly the same conclusions as the paper's authors regarding financial stability. Financial stability, he noted, is a question of business models, franchise value, and regulation. Regulation has made the system safer, but there is also a trade-off. Although the franchise values of many investment banks have deteriorated, and the ability to make loans and take deposits has been squeezed to some extent by the net interest margins and low interest rates, the gap between the cost of capital and the return on capital does not really exist for "plain vanilla banking," as opposed to investment banking. He posited that before the financial crisis, there was probably too much investment banking.

Kohn also commented on resolution, echoing Hall's remarks. "The big task is making resolution work and making it credible," he said. His sense was that resolution is more credible in the United Kingdom than it is in the 
United States, but one really cannot know for sure until it is tested. Kohn also asked what the authors thought their paper's implications were for "too big to fail." In that regard, he was encouraged to see that banks looked a little riskier postcrisis, implying that the market was putting less weight on the notion of too big to fail.

Last, Kohn brought up the issue of stress tests. Financial regulators rely heavily on the results of these tests. Regulators force banks to write down their assets under severely stressful hypothetical conditions and to report what their losses would be. After the fact, finding out what capital they have left after the stress should provide good information about their underlying resilience, despite the fact that many assets and loans on their balance sheets are not marked to market.

Martin Baily complimented the authors on a terrific paper, one he hoped would shake up the debate about bank safety in a constructive way. Baily had thought the stress tests were doing a better job in assessing bank safety than was described in the present paper. The tests are organized strangely, he noted, because the banks do not know exactly how the tests are conducted. The Federal Reserve does not specify the parameters of the stress but, beyond that, bank regulators say that they do not want to give away the details because they do not want the banks to game the test. That may be a reasonable concern, he stated, but it has created a confusing environment both for banks that are taking the test and for outside observers to understand whether the tests are doing a good job at measuring bank safety. The stress tests do look at the amount of regulatory capital held by the banks and not the market value of equity. On the other hand, the tests evaluate whether or not the institutions remain viable in very difficult economic and financial scenarios, and regulators do look at bank earnings. These tests should, in principle, give a picture of whether the banks are stable to severe shocks. Baily hoped the authors would do more to explain why they thought the stress tests were failing so badly.

One of the implications of the paper, Baily noted, is that banks are less safe because they are less profitable, a message he thought was provocative. He explained that, in the precisis period, the U.S. Treasury Department's Office of the Controller of the Currency allegedly would argue that a profitable bank is a safer bank, and therefore that it wanted banks to be more profitable. According to Baily, this is no longer the view because of the hostility toward the profits that were generated from risky and complex assets prior to the crisis. He was curious as to what the authors thought the right level of profitability was and, presumably, what regulatory structure would be needed to generate it. He was puzzled to observe that, though the 
banks have been given extra costs-so their costs of operation are quite a bit higher-they do not seem to be charging borrowers higher spreads. Presumably, this is because the market for borrowing is not very good; but it is puzzling that banks are not able to recover some of their profitability through higher returns on loans.

Baily agreed with Hall about the value of a single point of entry and resolution, and he thought that the system is somewhat safer than one would judge from the Volatility Institute's measures of systemic risk, because it is now possible to resolve future problems with the largest financial institutions without bringing the whole system down. The operating subsidiaries of failing banks - the parts essential for systemic stability — can continue to operate during crises.

Benjamin Friedman's remarks followed Baily's in focusing on the profit and loss statement that goes along with the balance sheet. He thought that the paper usefully focused on balance sheet issues, but that the profit and loss aspect of modern banking raises all sorts of issues. He recommended work by Andrew Haldane, which showed that for the 29 largest international banks deemed by the global authorities to be systemically important, in aggregate, more than 100 percent of their profit was due to the too-bigto-fail subsidy from the governments. ${ }^{1}$ According to Friedman, this implied that these banks did not have a business model that enabled them to be profitable on a stand-alone basis. Then the question is, where does one go from here? According to Friedman, the usual presumption is that this is a terrible problem, and it is up to the government to do something with its regulation to make banks profitable. But it was not obvious to him why this was so. If a business or an industry has no business model that enables it to be profitable, usually economists come to a different conclusion. According to Friedman, it is not hard to imagine various changes in the business model of banks that could make them profitable without new regulations. To take just one trivial piece of the story, Friedman observed that in most cities in the world, most of the highest-priced real estate is used by banks. Is it natural that this is the case, he asked? Is this the only business model one could imagine for getting this activity done?

Friedman expressed his hope that if Haldane's work were ever redone with more recent data, it would be useful to see it presented in a way that

1. Andrew G. Haldane, "On Being the Right Size," speech given at the Beesley Lectures, Institute for Economic Affairs, London, October 25, 2012 (http://www.bankofengland.co.uk/ archive/Documents/historicpubs/speeches/2012/speech615.pdf). 
would correspond to the present paper, though he suspected that the bottom line would be the same- that these banks do not have a business model that enables them to be profitable in the absence of a government subsidy. According to him, it is not clear that the answer to this is to make the subsidy bigger.

Frederic Mishkin was confused as to why the authors' measures seemed to say that the banking system was riskier now, while regulators would say the system was safer. He posed the following scenario: Suppose a regulation is put in place to remove the subsidy to risk-taking by the largest banks. As a result, the largest banks are less likely to fail. However, their franchise values are greatly diminished, and thus there is a big reduction in the value of the firm's equity. Such a regulation appears to increase financial stability, while at the same time hurting the banks. Mishkin asked the authors to explain if and how the scenario he had described was inconsistent with their conclusions.

Christopher Sims noted that the paper argues that if the problem before the financial crisis was that the risk of disaster was underestimated, and we have shifted to a higher estimate of the risk of disaster since the crisis, one should have seen serial correlation in equity values before the crisis. Sims believed this would only be true if the shocks occurring before the crisis were information shocks, where the uncertainty was being resolved within the precrisis sample. If there were, for example, a 0.1 percent chance of disaster before the crisis, and information was coming in that was shifting people's judgment of this between 0.05 and 0.15 percent, then that would have small effects on valuation. The same proportional shifts after the crisis, when the risk of disaster is 1 percent, would produce higher volatility, and in neither case would there be serial correlation.

Julia Coronado thought it was a bit ironic-maybe even profoundly ironic - to use precrisis market pricing as some kind of benchmark of safety when it is known that banks were generating an artificially stable stream of profits based on activities that were systemically risky and hidden from the public. Postcrisis, it is understood that there is more risk, and so it is priced in. Franchise value and the return on assets have come down, which is what regulators wanted to happen, because banking is risky. The whole ecosystem is reformulating and restructuring; banks are selling off units and getting out of activities. "Hallelujah! They should be riskier," she exclaimed. Banks are risky, and they are going to need to find a way to have a profitable business model. But this does not mean that regulation has failed, and that there is a problem the government needs to solve. The financial system is reformulating itself to take appropriate risks and find sustainable business models. She concluded that the focus does need to 
be on resolution, living wills, and making sure that the government is not expected to step in and bail a bank out.

Alan Blinder wondered what the authors had to say about the hypothesis that, when it comes to bank safety, the markets got it wrong in the 2004-07 period. To most economists, this was a crazy period, and by Blinder's reading, the authors appeared to rely on it as the basis of comparison. $\mathrm{He}$ apologized if the answer to his question was buried in footnotes, but asked the authors if they could take some of the measures back further in time so that the comparison period-the norm-was not the crazy time from 2004 to 2007.

Summers responded first by saying, on behalf of his coauthor, that he was thankful for the many helpful comments. "The uncharacteristic humility that I displayed on the question of all the policy implications of this was actually genuine, and I've learned a great deal from this conversation," he said. As a general comment, he stated that if one believes that the U.S. financial system is headed toward a splendid new world, where there will no longer be implicit government guarantees of any importance shaping banking systems, failures will be very successfully handled in the same way that failures of app startup companies are handled, and that all this is leading to a successful readjustment of the banking system. If one believes this, then Summers was not sure that the market evidence in the paper could convince that person that he was wrong. However, he asserted that he thought it an absurd thing to believe as a statement about the world as it stands presently. He acknowledged having read reasonably carefully the authorities' statements on these matters, concluding that this is not what they believe. On the contrary, they believe that progress is being made, and it is going to be OK with resolution authority and so forth.

According to Summers, if one were to read the collected utterances of Mark Carney, chairman of the Bank of England's Financial Policy Committee, who generally speaks for the global regulatory community, one would conclude that he is putting most of his chips on the view that the system is substantially better capitalized - and therefore failure is less likely, relative to the risks - and only putting a few of his chips on making resolution into something that is successful. Summers conceded that he had nothing to contribute, at this point, to the debate about whether resolution will be successful and could be successfully attempted sometime in the near future.

If one's belief is that everything is OK based on resolution authority rather than on the idea that big institutions will not fail, then the present paper should not shake one's belief, noted Summers. If, however, one's belief was that it is much less likely today than it used to be that there will be events causing the equity value of banks to go below their ATM fee, and 
in which there comes to be enormous doubt about whether they will be able to service their debt securities with equity assistance, then he submitted that the market evidence in the paper should give one very substantial pause as to whether this has been achieved. It should give one pause because the single measure that was most predictive in the cross section before 2008 is now substantially lower than it was at any point before the financial crisis. Further, it should give one pause because the delta on out-of-the-money put options suggests that these options are significantly more likely to be in the money than has been suggested in the past.

This should call into question, Summers continued, the view that the system is substantially less levered, on the simple argument that if the system had been more levered than it is today, the value of bank equity should have moved up or down by less than it did. If this is what one's argument was relying on, Summers claimed that the present paper should "very substantially shake one's complacency."

Turning to a variety of specific points, discussant Thomas Philippon had raised the possibility that something exogenous has happened that makes financial disasters more likely today. Summers conceded that perhaps this was right, and that he wanted to look more into it. He found Philippon's comments on the various determinants of what had happened to the return on assets to be very thoughtful and constructive, and he stated that there is obviously a large area that could be explored without fully understanding how much of the decline in profitability or perspective profitability reflected in markets is due to lower interest rates, changes in the regulatory environment, and general industrial organization meeting the banking system, and how much is due to the perceived erosion of the perception of being too big to fail. Summers did not claim to have broken this down, though the paper's authors did make the point that whatever has happened has been a substantial headwind.

With respect to the question that several people raised regarding stress tests, Summers believed it would be a good idea to say more about this in the paper. Oversimplifying his understanding of this enormously complex subject for the sake of this brief discussion, he posited this scenario: Suppose a loan is given to a shopping center at a 2 percent interest rate that balloons after 10 years. The shopping center goes down in value by 60 percent because there is a real estate collapse in the United States. The center's owners can continue servicing the 2 percent interest rate, and they can continue doing this in a healthy way that has played out for two years and is expected to play out for another year or two. How would one evaluate the equity capital of the bank in this scenario, recognizing that the balloon 
is highly problematic? Summers argued that the stress test methodologies do not take proper account of the duress in which the bank is likely to find itself in this case.

Summers agreed with Kohn that the paper should say more about investment versus commercial banking. He suspected that a very important aspect is that deposit insurance continues to be vastly underpriced. Instead of thinking about investment banking as having been eroded and commercial banking as being healthy, a better way to think about them would be that the value of subsidies to investment banking has declined by much more than the value of subsidies to commercial banking. If one were to only take away too-big-to-fail subsidies, in the simplest model one might expect equity to become less volatile because, without these subsidies, some of the volatility in assets would fall on debt, whereas in the presence of the subsidies, all of it would have a tendency to fall on equity.

Summers agreed with Sims's comment, but he thought it was slightly unfair in the sense that it was not quite reasonable to expect the present paper to have tested Philippon's hypothesis rather than the hypothesis the authors said they would be testing, which was about the general tendency to underadjustment during the earlier period. He thought that Blinder's idea of going back further was a good one, and that if one did that in a fair-minded way, one would be quite surprised to find that the banking system today looked substantially safer than people thought it was 10 or 15 years ago.

Summers was curious about the question of, if some kind of disastrous, exogenous event that would wipe out the banks were perceived to be significantly more likely, whether most of these events would probably also be expected to wipe out a good deal more than the banks. He would be surprised if markets in general were now pricing in a substantially greater probability of a disastrous event than they used to do.

He reminded Hall that the balance sheet of Chrysler or General Motors was not nearly as large as the balance sheets of major financial institutions, and that governments have a way of reaching judgments that their failure cannot be handled through resolution authorities. Of course, he noted, these might be erroneous judgments, but he thought he would be cautious about having excessive serenity about the efficacy of a resolution authority.

Finally, Summers concluded by saying that it is worth briefly reflecting on what was not talked about much: the international aspects. Though considering banks as being too big to fail is seen as the besetting problem of policy toward financial institutions in the United States, in many parts of Europe the achievement of being too big to fail is the central objective of financial policy. 